Article

\title{
The Possibilities of Preservation, Regeneration and Presentation of Industrial Heritage: The Case of Old Mint "A.D." on Belgrade Riverfront
}

\author{
Marko Nikolić(D, Boško Drobnjak® and Irena Kuletin Ćulafić * \\ Faculty of Architecture, University of Belgrade, Bulevar kralja Aleksandra 73/II, 11000 Belgrade, Serbia; \\ marko@arh.bg.ac.rs (M.N.); drobnjak.b@arh.bg.ac.rs (B.D.) \\ * Correspondence: kuletin@arh.bg.ac.rs
}

Received: 28 May 2020; Accepted: 25 June 2020; Published: 29 June 2020

\begin{abstract}
This paper aims to explore industrial heritage of Belgrade that is located in the city center and therefore, has considerable potential for future architectural and urban development of the Serbian capital. The whole Belgrade riverfront area along the Sava and the Danube Rivers has a large number of abandoned industrial buildings that have significant value and need to be preserved and revitalized. This paper represents a research project conducted by lecturers at the Faculty of Architecture in Belgrade in the course History and Theory 1-Visual Culture in Architectural Theory and Practice. In order to provide productive research, we have employed the case study method based on the old Mint "A.D.", which we have chosen as a characteristic example of Belgrade's industrial heritage architecture. An important goal of this research is to provide professional information and raise public awareness about the importance and potential of industrial heritage for the future economic, cultural, social and tourist development of the city. This paper analyzes possibilities to comprehend the problems of the city's industrial heritage protection regarding its historical and urban context, its genesis, authenticity, identity, cultural, architectural, economic, social, productive, creative and environmental values. According to that, the main goal of this research is concentrated on the sustainable preservation of specific cultural tangible and intangible values, spirit of the place, city identity and historic cityscape values that characterize industrial heritage in the social, cultural, natural and built environmental systems.
\end{abstract}

Keywords: industrial heritage; Belgrade riverfront; protection; regeneration; sustainability; educational projects; environmental approach to architecture and urban design

\section{Introduction}

Belgrade is one of the oldest cities in Europe, built on the confluence of the Sava and Danube Rivers. It is the intersection of Western and Eastern Europe. Belgrade integrates layers of rich historical and multicultural values, from prehistoric and ancient Roman times, through the Middle Ages, Ottoman and Austro-Hungarian influences to socialist and post-socialist cultural heritage. In this rich cultural setting, architecture and city planning were always carriers of significant cultural, social and ideological values [1]. The area of Belgrade along the banks of the Sava and Danube Rivers has a large number of abandoned industrial facilities that have significant monumental value, which should be preserved and revitalized. Some steps in that direction have already been taken, and some industrial buildings and plants represent significant sights in the tourist offer of the city. In the last decade, the construction of new architectural and urban projects on the Belgrade riverfront has resulted in negative impacts on the cultural heritage of Belgrade and the historic cityscape, which contains a characteristic urban morphology and typology that is gradually declining. In order to stop this 
tendency and modify it in accordance with the principles of sustainable development, it is necessary to redefine the approach to protection and revitalization of industrial zones by creating a new approach to protection, conservation and construction in former industrial zones. This should be done while taking into account various value parameters, yet with respect for the tradition, authenticity and identity of these specific cultural spaces.

In that sense, in the master academic study programs in architecture and integrated academic studies of architecture, in the course History and Theory 1-Visual Culture in Architectural Theory and Practice, we started a research project exhibiting the discovery of adequate opportunities for protection, revitalization and presentation of the Mint "A.D." in Belgrade. Through various conceptual solutions, the students emphasized the importance of the cultural-historical, urban and architectural values of the building and its ambience. The goal was to define sustainable solutions that would protect all phases of development of the complex, while respecting the basic principle of protection and revitalization, which is based on preserving the authenticity and monumental values of each historic building. On the other hand, the proposals were aimed at a common goal—to reactivate the complex and make it useful-as well as to integrate it into its immediate environment. The students proposed a range of modern cultural, educational and artistic ways to use the complex, which would be in line with its character and significance, as one of the successful ways to realize its active future and inclusion in modern life.

Unlike the total architectural heritage, which spans to hundreds or even thousands of years, the horizon of observing industrial heritage is narrowed to several centuries, even dozens of years. This is influenced by the following two facts: (1) Industry began to develop only a few hundred years ago, with an intensive rise in the second half of the 18th century, after the so called "industrial revolution" in England, and especially in the last few decades, following the progressive and accelerating development of new technologies in almost all areas of human activity; and (2) Industry itself, due to its properties, is "self-destructive", i.e., in accordance with new technologies and new methods of work, it constantly innovates processes and removes, changes, and even destroys existing means of production and infrastructure, including buildings and the immediate environment. However, in addition to that, it is clear that there is a general social interest in preserving this time-limited and specific form of heritage, as a witness to the development of technologies and technical culture, for future generations. This interest is acknowledged all over the world, and serious measures have been taken in recent years [2].

The Industrial Revolution is considered one of the most significant events in human history that has strongly influenced human society. Therefore, all the material and intangible heritage related to industrialization represent extremely significant historical evidence of the development of technology and human society, which are part of the collective cultural history of mankind. In the 1950s, industrial archeology was formed as a systematic study of structures and artifacts as a means of increasing human understanding of the industrial past [3].

In accordance with legal acts and protocols for the safeguarding of world cultural heritage, the concept of industrial heritage is defined [2,4-8]. Industrial heritage consists of the remains of industrial culture which are of historical, technological, social, architectural or scientific value. These remains consist of buildings and machinery, workshops, mills and factories, mines and sites for processing and refining, warehouses and stores, places where energy is generated, transmitted and used, transport and all its infrastructure, as well as places used for social activities related to industry such as housing, religious worship or education [2].

Serbia is one of the late industrialized countries that was affected by the process of industrialization only in the mid-19th century. In Serbia, industrialization was associated with the process of creating an independent country liberated from centuries of Ottoman rule, which entered the united state of the Yugoslav peoples at the beginning of the 20th century. The industrialization of the country was one of the key pillars of economic progress of the young Yugoslav state between the two world wars, 
and especially after the Second World War, when numerous and diverse industrial productions were launched throughout the SFRY according to socialist principles of self-government $[9,10]$.

At the beginning of the development of industrialization, industries were located on the very outskirts of city centers. The wider area of the case study-Mint "A.D." (Figure 1) — confirms this, where numerous industries were located in the area stretching from Belgrade Fortress (the old fortified city) to Ada Ciganlija (the Belgrade Lake).

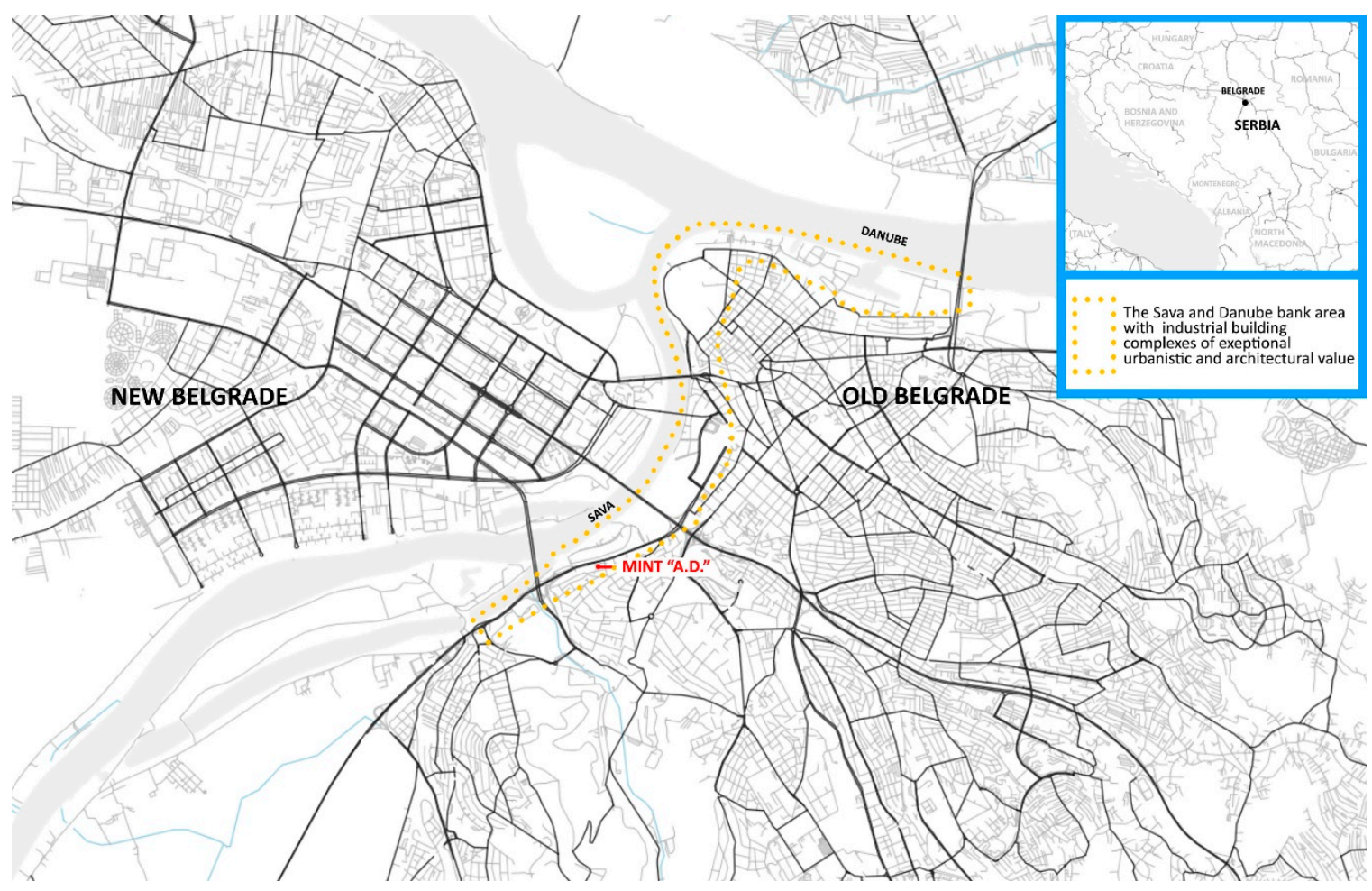

Figure 1. Map of the Belgrade and the position of the Mint "A.D." Source: Scribble Maps (redrawn by authors).

By overcoming technologies, organization and work processes, these industries were left with unresolved issues of ownership-abandoned, dilapidated and devastated. Until ten years ago, industrial heritage was not recognized at all as a type of cultural heritage that constitutes an important element of the identity and history of Belgrade. Industrial buildings were considered a mockery, a disgrace, a meeting place of the aesthetics of the ugly in architecture. The public and city authorities were not aware of the great potential of this specific type of heritage, which, with adequate protection and renovation, could become a successful driver of economic, social, tourist and cultural development. Through the engagement of non-governmental organizations and private initiatives in recent years, industrial spaces on the Sava and Danube riverbanks are being revitalized and reused, filled with various creative purposes, which are becoming recognizable for tourists outside the borders of Serbia. The area in the immediate vicinity of the Mint "A.D." became one of the most attractive parts of the city, due to the construction of the megalomaniac project "Belgrade Waterfront", which completely restructured and changed the centuries-old appearance of the Belgrade riverfront [11].

This is a privately funded project supported by the Government of the Republic of Serbia. The project "Belgrade Waterfront" is a typical example of the so called globalist "Dubai style architecture" with skyscrapers, towers and lamellas of residential, business, commercial content, as well as mixed-use spaces. The entire project, from the beginning of development of the first plans to the final works, many of which are still ongoing, is experiencing great public criticism in the local media and in public forums [12]. The main issue of the controversy over the "Belgrade Waterfront" project is focused on 
the environmental and urban inadequacy of this project, which has significantly endangered existing natural and historic structures, neglecting the potential for protection of industrial heritage in this area. On the other hand, the project "Belgrade Waterfront" is the largest architectural and urban endeavor with the aim of building a new modern center of Belgrade.

Although the embodiment of globalist goals of the economy of liberal capitalism, this project has the opportunity to revitalize this area with appropriate integration of existing industrial structures and other cultural heritage, while at the same time, respecting the principles of sustainability, environmental compatibility and protection of cultural heritage. Since the area of the Belgrade riverfront in the central zone of the city will be built over a decades-long period, all plans for future construction should comply with item 4.9. of the Resolution 1924 for Industrial Heritage in Europe (2013) and introduce measures to safeguard relevant disused industrial heritage sites from destruction, particularly in urban areas where land values are high [4].

The main results of this research project consist of provided documentation and archives about industrial heritage in Belgrade. Furthermore, through educational student projects, we elaborate on different approaches in presentation and contemporary regeneration of old Mint "A.D.", taking into account the progressive touristic development of Belgrade, as the place famous for amazing entertainment, gastronomy, hotel and restaurant services, and opulent social life. In this regard, regenerative research projects of the Mint follow sustainable solutions, making this remarkable industrial heritage active, useful once again, and reintegrated in a prosperous and inclusive environment.

Since we are teaching at the University of Belgrade-Faculty of Architecture, we consider the topic of preservation, regeneration and presentation of industrial heritage a very current and useful research issue for our students' education. To this end, our research also includes their educational projects. We based our educational work on the crucial importance of environmental and sustainability knowledge regarding architecture, urban development and heritage protection and revitalization. Taking into account Serbia's low level of involvement in sustainable and environmental practices (Serbia is classified as a developing country regarding the implementation processes of sustainable development), this research could be useful for Serbian governmental institutions which are dealing with legal procedures and regulations in the domain of sustainable development and global environmental goals [13].

Our paper aims to raise awareness among city authorities, cultural and touristic institutions, investors, architects, city planners, local community inhabitants, creative stakeholders and architecture students about the importance of industrial heritage and its preservation for integration into the urban fabric and raising the level of environmental awareness and sustainable design in architecture and urban planning. The paper is intended for these target groups as we believe that this type of project research would contribute to expanding knowledge in terms of theoretical and practical activities in modern Belgrade, with the main goal of sustainable architecture and respect for principles and recommendations of international charters and efforts of institutions responsible for cultural heritage. The research projects of the Mint "A.D." presented in this paper try to highlight the appropriate and adaptive reuse of industrial heritage as the first and very important step towards sustainable architectural building and maintenance of the existing historical cultural heritage.

In today's practice, the leading cultural institutions dealing with the protection of cultural heritage give priority to other forms of cultural heritage, while the importance of industrial heritage is marginalized. A major shortcoming is the lack of laws and legal procedures concerning industrial heritage protection and revitalization. It is important to emphasize that this research project of the industrial heritage of Belgrade emphasizes the fact that the industrial heritage of Serbia is part of European scientific and cultural heritage. In this regard, without the connection and cooperation of Serbian institutions with world institutions, it is not possible to achieve planned goals in the conservation and preservation of Serbian industrial heritage. With this in mind, this paper examines in detail the legal bases concerning various conventions, recommendations, acts, agreements, etc., on the basis of which European and countries worldwide work in relation to industrial cultural heritage. 
In Serbia, the head of the Council for the Protection of Industrial Heritage and the main bearer of the initiative for protection and preservation of industrial heritage is the Museum of Science and Technology. In addition to numerous museum departments that have very important documentation and material goods related to Serbian scientific and technological history, this museum has a special department dedicated to industrial heritage. The Museum of Science and Technology in Belgrade in cooperation with Republic Institute for the Protection of Cultural Monuments of Serbia, Belgrade City Institute for the Protection of Cultural Monuments, academic staff and experts, advocate for the adoption of a single legal act that would enable tangible and intangible cultural property to be placed under integral protection in accordance with the existing laws of the Republic of Serbia [14].

In order to promote the integral protection of industrial heritage on the territory of the Republic of Serbia, many professional institutions, including the University of Belgrade-Faculty of Architecture, prepare projects, studies and exhibitions aimed at researching, promoting and popularizing Belgrade's industrial heritage. These actions result in the further goal of recognizing the industrial heritage of Serbia by global and European organizations dealing with the protection of industrial cultural heritage, such as United Nations Educational, Scientific and Cultural Organization (UNESCO), International Council of Monuments and Sites (ICOMOS), International Committee for the Conservation of the Industrial Heritage (TICCIH), Association for Industrial Archaeology (AIA), Society for Industrial Archeology (SIA), European Route of Industrial Heritage (ERIH), European Federation of Associations of Industrial and Technical Heritage (E-FAITH), International Committee for the History of Technology (ICOHTEC), United Nations World Tourism Organization (UNWTO), Europa Nostra, and other organizations.

The focus of this paper is based on research into the importance of Belgrade's industrial heritage, its preservation, revitalization and presentation in accordance with the goals of sustainability and environmental protection. In other words, the focus is on local sustainable architecture which aims to create new social practices and new social relations [15], referring to the fact that sustainable architecture absorbs a rather complex integration polygon of cultural, ecological and natural factors in the material practice of shaping social reality [16]. Through the analysis of student proposals for reactivation of the Sava riverfront with special emphasis on the industrial complex of the Mint "A.D.", a significant contribution was made to a critical review of current approaches to protection, revitalization and presentation of Belgrade's industrial zones, all in order to find recommendations and guidelines for further urban development and preservation of authenticity and identity of industrial heritage. The relation of the application of spontaneous or imposed contents in the processes of reuse of industrial heritage is especially considered [17].

\section{Materials and Methods}

The case study method was chosen in order to best explain and show the causal connections in practice on a concrete example of an empirical architectural study of the reconstruction and protection of the Mint "A.D.". The paper adopts the main methodological principle that theory should produce a platform for practice, on the basis of which detailed analyses of the selected case study have emerged. It is a reversible process in which theory informs practice, and practice informs theory. Having in mind the extensive research conducted by professors from the University of Belgrade-Faculty of Architecture and long-term educational practice, it is important to emphasize that, in research work on the subject, students are not only passive listeners, but are required to participate in an inclusive and multidisciplinary way. They are encouraged to express their theoretical knowledge acquired in the lectures in design practice through their projects of presentation of reconstruction and protection of industrial architecture.

The method of content analysis was used in the initial stages of work in documentation research, international legal policies, acts and conventions, foreign examples of successfully performed adaptive reuse, analysis of plans, projects and industrial buildings on the researched area of Belgrade riverfront stretching from Belgrade Fortress to Ada Ciganlija. Methods of classification, comparative analysis, methods of abstraction, specification, concretization and generalization were further used. Based on 
the analyzed data, mapping, identification and recording of current status, formation of archives, photo documentation and databases were performed. In the final phase of the work, synthesis, systematization and valorization were carried out, followed by proposals for presentation solutions for conservation, renovation and reuse of the industrial zone included in the Mint "A.D.". As a final part of the paper, a table of valorization of the success of conservation solutions was formed, where different evaluation criteria were determined in detail.

\subsection{Industrial Heritage and Relevant Charters}

In the research methodology through the selected case study, we were guided by the criteria of systematicity and critical analysis. The entire research work is based on a detailed research of the theoretical foundations on which the legal basis of protection, conservation, adaptive reuse of industrial cultural heritage and architectural and urban design in the vicinity of this heritage are based. The first phase of the methodological procedure included the consideration of numerous charters, conventions, agreements and laws concerning industrial heritage and its sustainable preservation.

One of the most important documents that defines the role and significance of industrial heritage in the context of general world cultural heritage and universal human values is The Nizhny Tagil Charter for the Industrial Heritage (2003) [2]. The Nizhny Tagil Charter aligned with the propositions of the Venice Charter (1964); Convention Concerning the Protection of the World Cultural and Natural Heritage (1972); Convention for the Protection of the Architectural Heritage of Europe (1985); Convention for the Safeguarding of the Intangible Cultural Heritage (2003) [5-8].

Industrial heritage includes all tangible and intangible evidence; documents, structures, human settlements, as well as nature and the built environment related to industrial processes, starting from the second half of the 18th century to the present day, but not neglecting earlier roots in the pre-industrial era [2]. It has been concluded that industrial heritage has great social value, as one of the important proofs of the life of ordinary people and their identity. It also has technological and scientific value related to the history of production, engineering and construction, but also significant aesthetic value in relation to its architecture, construction and planning. Industrial heritage is often neglected and thus, devastated, because its preservation is not considered as important as other types of heritage [18]. Therefore, the world has accepted the view that it is necessary to identify the entire world's industrial heritage, in order to preserve it for future generations. In addition, it is necessary to identify different types of industry and to create appropriate registers (with descriptions, drawings, photographs and films of the reference movable property). It is also necessary to include people's memories, which are often an irreplaceable source of data and as such, should be taken into account in order to cover various aspects of sustainability [19].

The Nizhny Tagil Charter further states that appropriate programs should be established for industrial heritage research, in the same way as for the heritage of other historical and cultural periods, which should be supported by appropriate state policy [2].

International cooperation is of great importance for the research and evaluation of industrial heritage, especially in the form of coordination, use and evaluation of common sources. Since industrial heritage is an integral part of cultural heritage, it is necessary to protect it by special legal acts due to its specifics. These acts should enable the protection of factories and machines, structures below and above ground, complexes and ensembles of buildings and the industrial environment. Industrial heritage conservation programs should be part of the general policy of economic development at the regional and national level. Therefore, governments should establish a special advisory body, which will give an independent opinion on the protection and revitalization of industrial heritage [2]. It is considered that examples of industrial heritage with exceptional values should be fully protected and that no interventions should be allowed on them, which would jeopardize their integrity and authenticity.

Authenticity is one of the basic qualifying factors in assessing the value of cultural heritage. It is the absolute value of a cultural asset that recommends it for inscription on the List of World Cultural and Natural Heritage [6]. Authenticity refers to a large number of criteria, such as the concept of spatial 
organization, structure of the building, stylistic elements on the building, applied materials, method of execution, ambience and environment. Some parameters that relate to intangible values are added to these ones, such as tradition, customs, spirit and sense of place. Authenticity cannot be observed in relation to one of the given criteria, but should represent the necessity of forming a joint critical judgement in relation to all criteria $[20,21]$. Proper understanding of authenticity plays a fundamental role in all scientific studies of cultural heritage, in planning, protection and revitalization projects.

Another important factor for the preservation of cultural heritage is the notion of integrity, which is a measure of the coherence and wholeness of natural and/or cultural heritage and its features. Both principles, authenticity and integrity, are focused on the ability of the observed cultural good to convey its significance. In the case of authenticity, it refers to the significance and cultural-historical value, and in the case of integrity, to the management and maintenance of the site so as to ensure its significance and cultural value over time. This means that a proper understanding of the principles of authenticity and integrity in projects implies respect for the existing values of historical complexes and buildings, as well as their adequate inclusion in the processes of valorization and adaptive reuse in accordance with modern times. The main goal of the protection of cultural goods is to transfer the value of the historical place and to include it in modern life in an adequate, sustainable and economical way. In that sense, the students were guided by respecting these principles of protection and revitalization, by preserving the spatial organization, construction, stylistic elements, as well as by the intangible values of the Mint "A.D." during their projects, which will be discussed in more detail in the following sections.

For this reason, renovations with measure and reusability are recommended as a convenient and cost-effective way for the survival of industrial buildings, and this should be encouraged by appropriate regulations, technical advice, incentive fees and patronage. The conservation of industrial heritage also depends on the preservation of the functional integrity of the heritage, and all possible measures should be taken to maintain it for as long as possible. The value and authenticity of a factory will be significantly reduced if machines and other equipment are taken out of it, as well as if auxiliary facilities that are part of the whole are destroyed. For this reason, in situ conservation is a priority [2].

The Nizhny Tagil Charter largely emphasized the importance of ensuring an appropriate positive public attitude towards industrial heritage. This signifies that the meaning and importance of industrial heritage should be actively explained, through publications, exhibitions, media, providing insight into the most important factories and other plants, with the promotion of sightseeing tours. Industrial heritage has a special cultural and tourist significance in terms of encouraging and activating the tourist development of urban areas in which it is located [22,23].

The next important document is Council of Europe Resolution 1924 for Industrial Heritage in Europe (2013), which emphasizes the importance of tangible and intangible components of industrial heritage through a common industrial heritage in all European countries [4]. Within this context of common values and common European heritage, Serbia participates in connecting its industrial heritage with other European countries, unlike non-European countries, where the process of industrialization took place in a different way [24].

For the research of the case study of the Mint "A.D.", we especially considered the following items of the Resolution 1924 (2013) which refer to: establishment of interdisciplinary research methods and multidisciplinary teams (4.4., 4.8.), treatment of industrial heritage sites as part of a wider social landscape interconnected with skills and local memory and identity (4.7.), measures to guarantee compliance with the character and integrity of buildings, as well as the character of the community (4.12.) regarding the partnership and interaction with other cultural resources and cultural heritage sites (4.14.) [4]. In item 5.1., special attention was paid to the role of cooperation between the European Union and UNESCO regarding the implementation of the Convention on the Value of Cultural Heritage for Society and the European Landscape Convention [25,26]. It is especially important to pay attention to environmental and sustainable aspects, and study which is the best way to reconcile ecological 
measures, building standards and risk prevention norms with the preservation of the integrity of industrial heritage (5.3.6) [4].

The European Urban Charter II (2008) points out that factories and machines from the industrialization period are often a neglected part of urban heritage. Industrial heritage as part of urban heritage is considered as an irreplaceable element of the urban fabric, essential for the city's identity. Therefore, adaptive reuse of old, industrial buildings and urban heritage can lead to economic approaches that include innovative mechanisms and partnerships, and thus, lead to successful urban economic regeneration [27].

One of the most important associations is International Committee for the Conservation of the Industrial Heritage (TICCIH), which is an international body that includes historians, conservators, curators, architects, archaeologists, students, teachers, and heritage professionals with an interest in the development and conservation of industry and industrial society. Although TICCIH includes both individuals and institutions, it is organized through national associations in those countries where there is a recognized national body for industrial heritage [28]. The role of TICCIH is to promote, protect and research the industrial heritage through research, publications and congresses. Serbia has recently become a member of TICCIH, and through some industrial companies and NGO initiatives in the last decade, Serbia has maintained regular contacts with TICCIH. Serbia participated in the 2018 TICCIH 2018 Congress held in Santiago de Chile [29]. In 2014, an agreement was signed between TICCIH and ICOMOS in order to form a general framework of cooperation activities, events, meetings and information exchange [30]. In line with the efforts of TICCIH, the role of the selected case study of the Mint "A.D." contributes to the building of a national knowledge fund on the protection of industrial heritage. With its methodology and materials on which the research relies, this paper contributes through educational projects.

Due to the high concentration of industrial heritage on the Belgrade riverfront, the urban area, stretching from the Belgrade Fortress to Ada Ciganlija Lake, can be treated as a kind of authentic industrial landscape. Having that in mind, in our paper, we have relied on numerous conventions, charters, declarations and recommendations, especially the ERIH Master Plan European Route of Industrial Heritage (2001), the ERIH Declaration of Duisburg (2001), the TICCIH Nizhny Tagil Charter for the Industrial Heritage (2003), the ICOMOS Charter on Cultural Routes (2008), the UNESCO Recommendation on the Historic Urban Landscape (2011), The European Landscape Convention (2000); Convention for the Protection of the Architectural Heritage of Europe (1985), etc., [2,7,31-39].

This methodology of work has enabled us to look at the wider area of the Mint "A.D." in a comparative way regarding cultural heritage and its social, environmental, economic and tourist potentials, in its integrity and integration with the natural environment and new urban structures. Therefore, in future development, the best protection of this area would be achieved if the industrial heritage of the Belgrade riverfront was viewed not from the aspect of the single monument, but as a unique industrial heritage site with significant relationships associated with its natural, cultural and historical setting [33]. Something similar was done in Germany in the Ruhr area-the Route Industriekultur was developed, which united 52 sites and 25 locations of industrial heritage. The project was implemented in 1999 by the regional association Regionalverband Ruhr [40]. The ERIH Executive Summary for European Route of Industrial Heritage begins with the words of a famous English poet William Blake, "I see the Past, Present and Future existing all at once before me" [32]. This profound thought best illustrates the pretensions of the European Route of Industrial Heritage (ERIH), an international organization established in 1999 with the enlightening goal to promote industrial heritage and culture through the networking of existing sites, with appropriate interpretation, information and signposting to enhance their tourism potential [32]. At the turn of the third millennium, the historical, cultural, intellectual-educational and tourist-recreational attitude towards the industrial heritage of the past centuries has changed a lot, which is confirmed by the ERIH Declaration of Duisburg. It emphasizes the importance of connecting European countries with regard to the protection of Europe's industrial heritage as a witness to European common history and identity [32]. The Declaration of Duisburg 
especially stresses the urgency of implementing sustainable redevelopment of industrial monuments and sites, advocating for a sustainable future in spatial planning, cultural heritage tourism and recreation, creating both shared and individual identities of nations [32].

The most important action plan of global effort regarding the common sustainable future of people and the planet is the Agenda Transforming our world: The 2030 Agenda for Sustainable Development [41]. The 2030 Agenda relies on other legal acts such as: Rio Declaration on Environment and Development (1992), the World Summit for Social Development (1995), the Programme of Action of the International Conference on Population and Development (1994) and United Nations Conference on Sustainable Development Rio+20 (2012) [42-45]. The 2030 Agenda contains 17 Sustainable Development Goals and 169 targets, which are based on the Millennium Declaration (2000) [46]. The 2030 Agenda seeks to achieve what the Millennium Development Goals have failed to achieve. The 2030 Agenda highlights economic, social and environmental as three key dimensions of sustainable development. The 2030 Agenda is linked to the Paris Agreement (2015) and the Kyoto Protocol (1997, entered into force in 2005), which represent the Framework Convention on Climate Change [47,48].

In terms of the essence of the Kyoto Protocol-carbon emissions and greenhouse effects-the countries of Eastern Europe are having a hard time meeting the requirements of this Convention with all their efforts. The Republic of Serbia ratified the Kyoto Protocol in 2007 [49]. The Kyoto Protocol is linked to the Doha Amendment, which was adopted for a second commitment period, starting in 2013 and lasting until 2020 [50]. Since 2010, Serbia has introduced the Clean Development Mechanism (CDM), which helps developed countries meet their commitments to reduce emissions and assist developing countries in achieving sustainable development.

The global climate has changed drastically in the last 200 years as a result of the industrial revolution. The negative consequences of global warming have greatly changed the philosophy, approaches and way of thinking in architectural construction, civil engineering and urban planning. For architecture and urbanism, the standing point of the Kyoto Protocol is very important. It is based on common but differentiated responsibilities, and emphasizes that each country has different capabilities in combating climate change, primarily depending on the level of economic development obligation to reduce GHG emissions.

In recent years, special attention from conservation institutions and experts engaged in the research and protection of cultural heritage has been focused on intangible cultural goods. Intangible aspects of industrial cultural heritage are also recognized in the Convention for the Safeguarding of the Intangible Cultural Heritage (2003) [8]. In the methodology of researching the possibilities of preservation and architectural and urban reuse of the Mint "A.D.", we put special emphasis on its intangible components, believing that human skills and production technologies carried out by workers in obsolete industrial production are of key importance, and they need to be adequately recorded, preserved and passed on to young generations.

The great wealth that lies in the intangible aspects of architectural heritage is often poorly used when it comes to renovation and reuse of architectural heritage. Given that in architecture, intangible heritage is inextricably linked to material tangible heritage, in this paper, we advocate an integral approach that will provide the importance of both the tangible and intangible assets of industrial heritage. The promotion of intangible components of industrial heritage in our case study creates multifaceted opportunities for creative and economically progressive development. Intangible heritage can be a very original management and branding tool for urban development, tourism, culture, entertainment, recreation, catering, etc., $[17,51,52]$. Cultural content is a valuable asset that can become a driving force if it is used to establish a "creative city", in cases of urban reuse [53].

In the management of the processes of urban reuse and planned development of the considered zones of the Belgrade riverfront around the Mint "A.D.", public, private and local community interests were taken into account. Decision-making strategies for urban development of the Belgrade riverfront for the case study of the Mint "A.D." are focused on bottom-up approaches, and not on top-down approaches that favor only the economic level of greater profitability, while not caring for authenticity, 
integrity, social, cultural, conservation, historical, symbolic, aesthetic and environmental values of architecture [54,55].

In order to explain, as precisely as possible, the stages of the methodological process, we created a diagram of values, principles and charters that regulate the system of protection, revitalization and presentation of industrial heritage, which we used in our work. The diagram (Figure 2) shows those charters that are most relevant for the research of industrial heritage as an element of an authentic and integrative sustainable wholeness of the architectural, urban and natural environment. The presented diagram illustrates the methodology of work on the course History and Theory 1-Visual Culture in Architectural Theory and Practice, which concerns the selection of those charters and legal regulations that are important for adaptive reuse and revitalization of industrial heritage in practice. The theoretical work carried out by the teaching staff through lectures is cyclically connected with the practical mentoring work on the development of revitalization projects for the Mint "A.D.". It is a cyclical methodological process that consists of the following units: (1) theoretical teaching and acquisition of knowledge, (2) application of theoretical and research knowledge in practice-project design, and (3) practice, i.e., the presented projects are followed by information and new knowledge that serve to create new and revise existing theoretical knowledge.

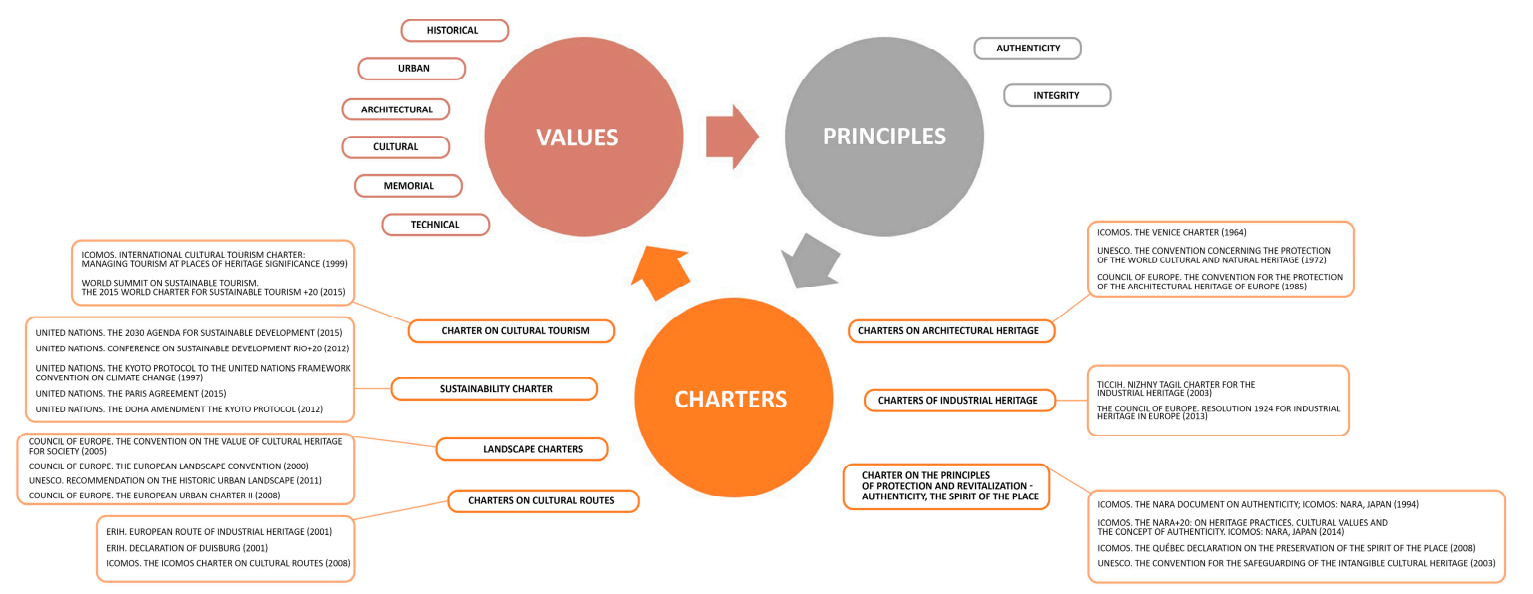

Figure 2. Diagram of the value of principles and international charters and recommendations in the field of protection, revitalization and presentation of industrial heritage.

The mentioned charters on industrial heritage more closely determine the attitude towards the preservation of industrial heritage, whose complexes and buildings have significant historical, cultural, urban, architectural, memorial and technical values. Charters and guidelines related to the interpretation of the main principles of protection and revitalization of cultural heritage can be singled out, primarily the interpretation of the concept of preserving the authenticity of a monument and its monumental values, through preserving the spatial organization, structure and stylistic elements of the building. Charters have also been appointed that more closely define the approaches to preserving the intangible heritage - the spirit of the place-because such spaces preserve important evidence of social and sociocultural values, through elements of tradition, customs, and people's way of life. It is especially important to point out the charters and guidelines related to the development of cultural tourism, as well as cultural roots of industrial heritage. The mentioned charters and guidelines in the diagram are current and recent, and the students were introduced to current international charters and recommendations in the field of preservation and protection of industrial heritage through lectures, which was a good theoretical basis for their further work on the conceptual solutions for the Mint "A.D.". The diagram shows a relation between international documents, the principles of protection and revitalization, as well as the monumental values of the historic site. In this way, we would like to point out to all professionals and future researchers, that it is necessary to use the guidelines given in these documents, as well as to respect and preserve monumental values through valorization, 
with mandatory respect for the most important principles of protection and revitalization based on preserving the authenticity and integrity of the historic site. The ultimate goal should be the revival of the monument and its inclusion in modern life, while always taking into account projects that will not violate these principles, which will enable the cost-effectiveness of such interventions.

\subsection{Practical Framework-Methodology of work on the elective course History and Theory 1-Visual Culture in Architectural Theory and Practice}

For many years at the University of Belgrade- Faculty of Architecture, students of master and integrated academic studies of architecture, within elective courses in the field of protection, revitalization and study of architectural heritage, have the opportunity to expand their knowledge acquired in basic academic studies in architecture history and art. Through various topics and types of architectural heritage, students have the opportunity to apply their acquired knowledge in projects of revitalization and presentation of historical spaces through concrete examples (Figure 3). In addition to various topics related to the ancient and medieval heritage in Serbia, students are given tasks and topics related to industrial heritage in Belgrade. During previous years, students have given very important ideas related to the renovation, revitalization and presentation of important buildings of industrial architecture, which are in very poor condition today, such as the Foundry "Pantelić" in Zemun and the Art Foundry "Skulptura" in Belgrade [56,57].

In the fall semester of the school year 2019/2020, at the University of Belgrade-Faculty of Architecture, we realized a course in the first year of master's academic or fourth year of integrated academic studies of architecture entitled History and Theory 1-Visual Culture in Architectural Theory and Practice.

The topic of research on the subject in this school year was related to the study of industrial heritage on the territory of the city of Belgrade, through the case study of the Mint "A.D." and the possibilities of its protection, revitalization and presentation.

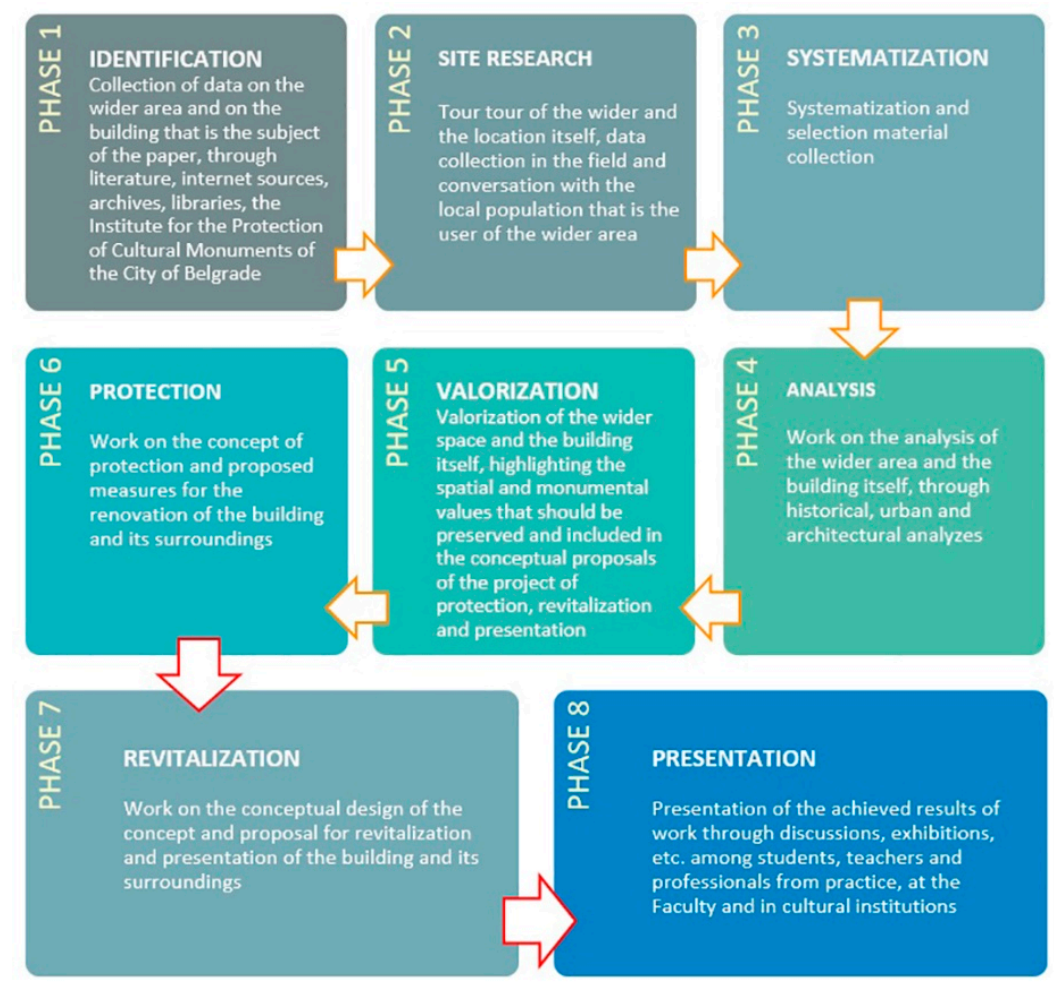

Figure 3. Methodology of work on research, protection, revitalization and presentation of historical sites and buildings. 
The students started their work by site research, research of the literature and of internet sources, in order to get better acquainted with the specifics of significant examples of industrial architecture in the world and in Belgrade. After researching the location, the students performed analyses of the cultural-historical, urban, architectural and technical values of the Mint "A.D." area and its surroundings, as well as an analysis of the current approach to the protection and presentation of this complex. Through lectures, students were introduced to the process of valorization of industrial facilities, so after collecting data on the example that will be processed (the Mint "A.D."), they focused on the valorization of the complex. They conceptualized their own views and ideas about this complex. After collecting basic data on the historical, urban and architectural development of the industrial complex of the Mint "A.D." and site research, students presented the results of their research with special emphasis on valorization and highlighting its values that should be incorporated into future proposals for renovation and revitalization of this important industrial heritage. Based on the results of the research, they proceeded to work on the design of proposals for modern interventions, i.e., defining the character of the future arrangement and presentation of the Mint "A.D." complex.

\section{Results}

\subsection{Industrial Heritage of Belgrade-Historical Overview}

Belgrade is the capital of the Republic of Serbia, located in the southeastern part of Europe, at the confluence of two important European rivers-the Danube and the Sava. Its position throughout history has decisively influenced the historical, cultural and urban development of the city. It is one of the oldest cities in Europe. The first settlements on the territory of Belgrade date from the prehistoric Vinča culture, around $4800 \mathrm{BC}$. The settlement itself was founded by the Celts in the 3rd century BC, before it became the Roman settlement Singidunum $[1,58,59]$. The close connection between the rivers and the city is one of the main elements of the specific historical and cultural identity of Belgrade, authentic urban morphology and special characteristics of the city landscape. The urban development of Belgrade at the beginning of the 19th century, after the establishment of the Serbian principality and partial political autonomy within the Ottoman Empire, was connected with the development of trade and river traffic, as well as with the establishment of the first production workshops. The political, economic and cultural center of the Serbian population was in the area around the Cathedral on the slope of the Sava River, in the area of Kosančićev Venac (Figure 4), the port on the Sava River and in the new part of the city called Savamala [60]. The area of the Sava port and the riverfornt was outside the fortified historical part of the city, which was surrounded by ramparts and a moat. The main communication link between Belgrade (in Serbia) with the city of Zemun (in Austro-Hungarian Monarchy) was located in the area of the Sava port. During the 19th century, new trade and transit roads were developed in this area, where important houses of famous merchants, hotels, customs houses, warehouses, etc., were built. The southwestern area of the city was undeveloped, predominantly swampy ground, called "Bara Venecija" ("The Venice Pond"). 


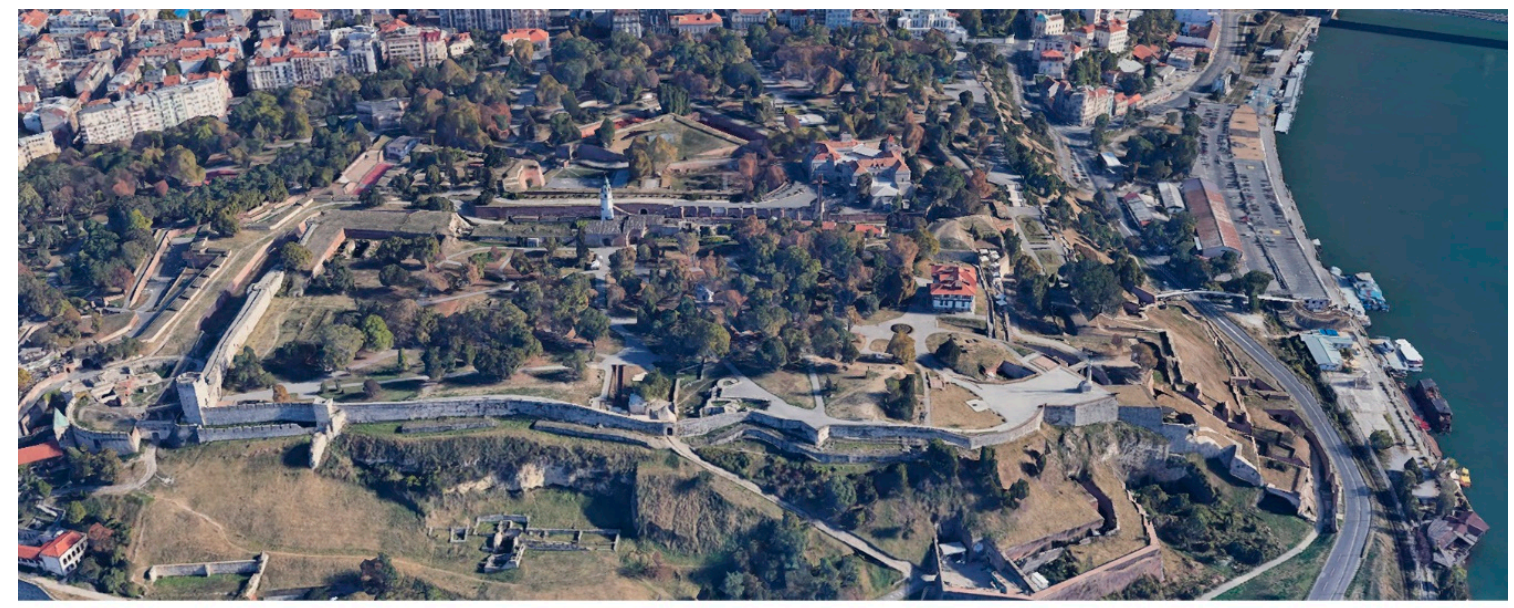

a

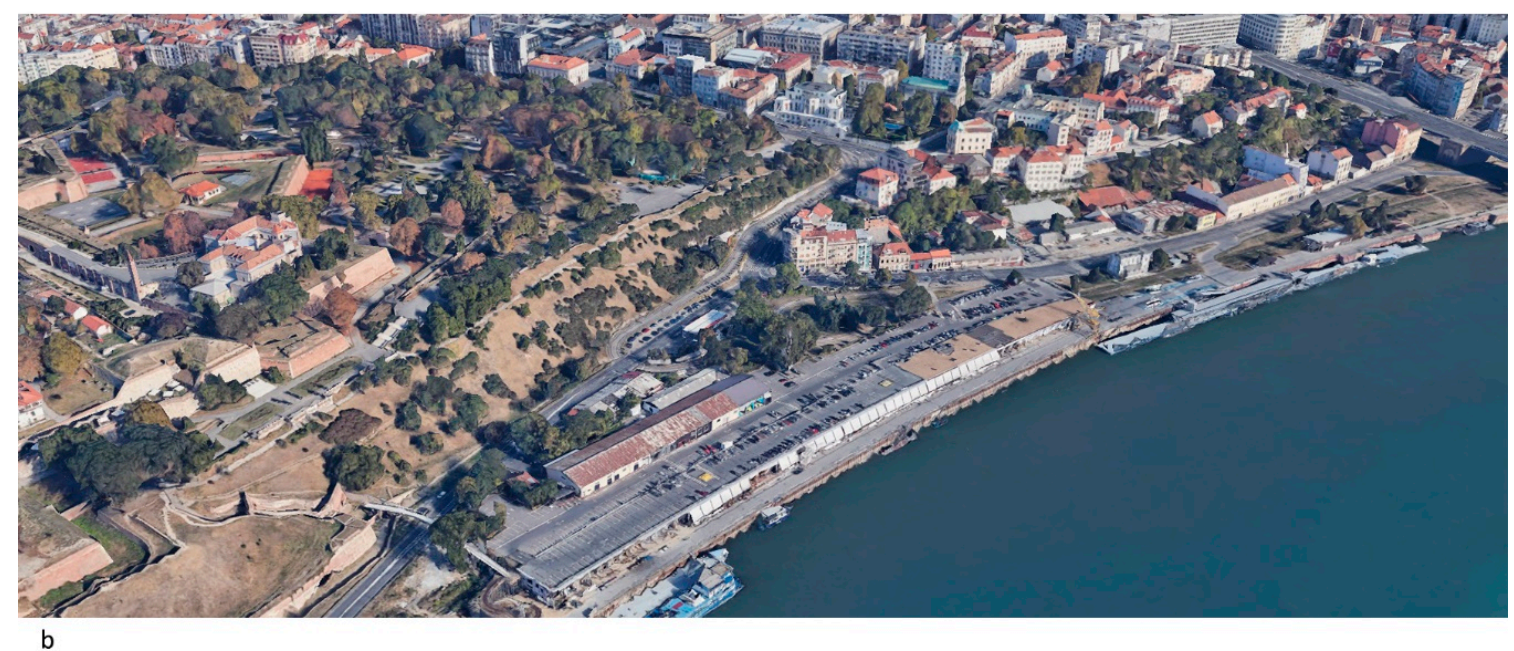

Figure 4. Belgrade from bird's eye view. (a) View of the Belgrade Fortress, (b) View of the Beton Hala and an urban neighborhood Kosančićev Venac. Source: Google Earth.

After the proclamation of the Kingdom of Serbia in 1882, stronger ties were established with Europe, especially with the Austro-Hungarian monarchy. More and more foreign capital was invested in Serbia and the first industrial buildings were built (Figure 5). Thanks to that, Serbia has had constant economic growth. This was especially accelerated by the construction of the railway from 1881 to 1884 and the first railway bridge over the Sava River (that connected Belgrade and Zemun). The development of the railway had a decisive influence on the future development of Serbia, and Belgrade became an important trade center and connection between Europe, Sofia and Istanbul [60]. The biggest changes took place around the former undeveloped area of "Bara Venecija", which was drained, and then, in 1884, the Main Railway Station was built. The railway that was built ran parallel to the banks of the Sava and Danube Rivers; it connected the new industrial areas on the Danube with the railway bridge on the Sava River, but in that way, the connection between the historical part of the city and the rivers was broken [60]. The first industrial slaughterhouse was built on the Danube bank in 1895 [61], and the Main Railway Station is still a significant proof of the urban, architectural and technical development of Serbia in the 19th century [62]. 

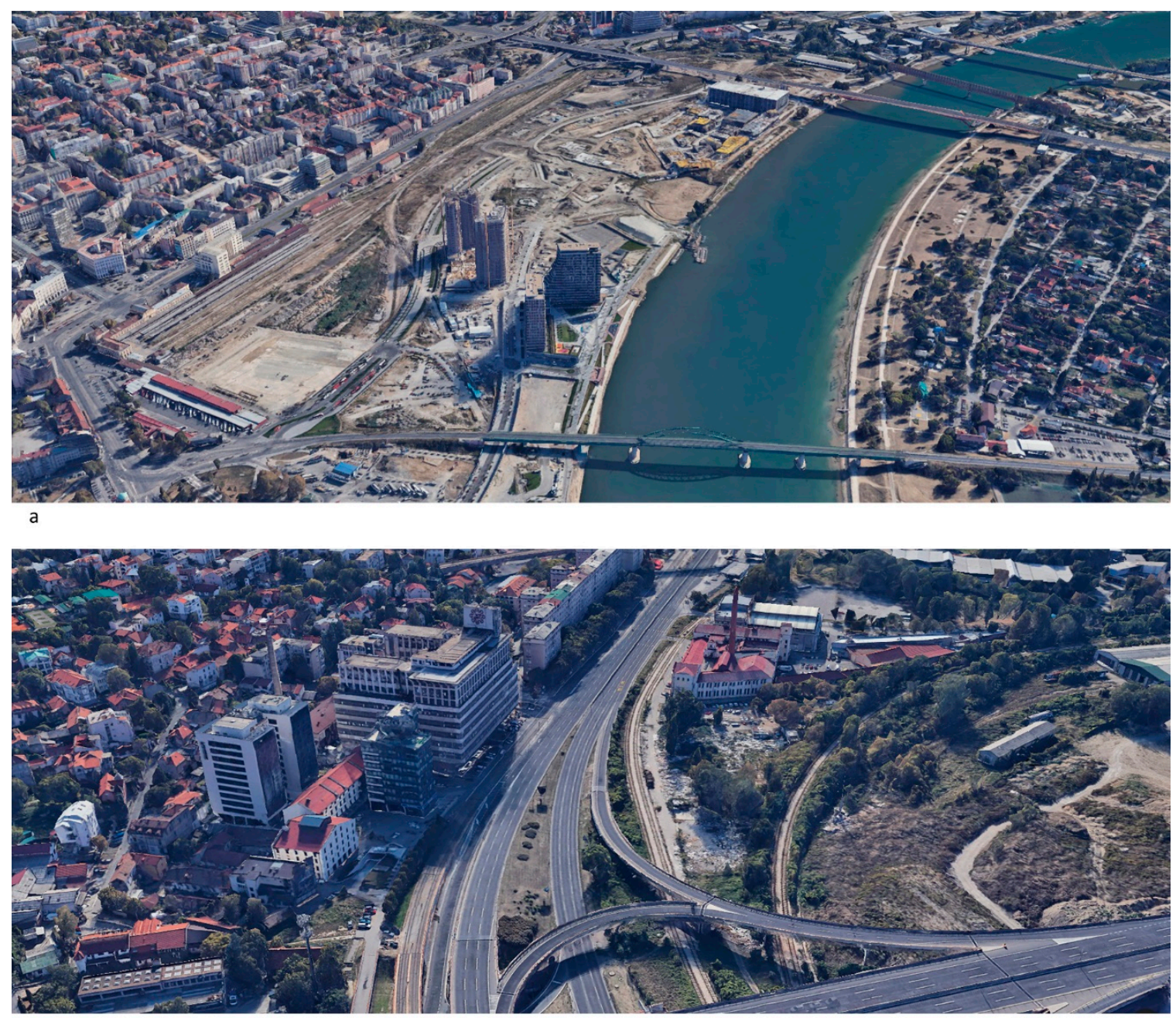

b

Figure 5. Belgrade from bird's eye view. (a) View of an urban renewal development project "Belgrade Waterfront". (b) View from the Mostar interchange at the Blvd. Vojvode Mišića. On the left are the Old Mill/Hotel Radisson Blu and State Printing House/"BIGZ" and on the right is the "Milan Vapa" factory. Source: Google Earth.

After the First World War, Belgrade was the capital of the new Kingdom of Serbs, Croats and Slovenes (later, the Kingdom of Yugoslavia) and developed rapidly. However, the city lost its centuries-old border position and large-scale reconstruction was planned. One of the main goals of the city's government was the development of modern infrastructure. The first major urban plan was completed in 1923, and one of the main highlighted problems was traffic, especially river and rail traffic, with such traffic being vital to the city's successful planning, growth and development in the future. In order to connect Belgrade with the Pannonian Basin, new bridges over the Sava and Danube were planned [63].

At the beginning of the 20th century, there were a total of 29 industrial buildings built along the Sava and Danube banks. During the 1920s and 1930s, that number increased very rapidly, so that in 1941, there were a total of 206 registered industrial facilities in Belgrade [64]. We can say that this industrial heritage is part of European heritage and identity, as a large number of industrial buildings were built by architects from Central European countries, especially Hungary, Austria, Germany and France. The architectural typologies of buildings were similar to European ones, although specific local elements could be noticed. One of the main industrial buildings from this period was the new City Power Plant "Snaga i svetlost" ("Power and Light"), erected in 1932 on the banks of the Danube [65]. 
Many buildings along the riverbanks were severely damaged during World War II by the German Armed Forces in 1941, as well as by the Allied Forces in 1944. Therefore, the period immediately after the war was characterized by the loss of almost half of the industrial factories, so the total registered number of facilities in 1950 was up to 90 . With the establishment of a new political framework and socialist state, significant changes took place in the industrial sector. In addition to the process of planned economy, the industrial sector was shaped by the process of homogenization of individual locations and production facilities. The spatial distribution of the production plants themselves remained unchanged, with a larger share of factories on the banks along the Danube. The period of the 1960s was characterized by a constant annual growth of industrial production, with an attempt to relocate production to suburban areas, as part of new processes of homogenization of industrial facilities. The period of the 1970s and 1980s was characterized by the process of relocation of industry from central urban areas, but also the opening of new facilities on the riverbanks [64]. The period of disintegration in the 1990s significantly increased the negative trend in the industrial sector and accelerated the processes of degradation and closure of numerous industrial complexes. This situation was underpinned by the effects of the war conflicts in the former Yugoslavia and the disintegration of the state, as well as the significant impoverishment of the newly independent states that emerged from the republics of the former Yugoslavia. With the disintegration of the former state, the Republic of Serbia and Montenegro became one state, only to finally separate, so that today, the Republic of Serbia is an independent state. This process, as well as the poor strategy of industrial production, further increased market fragmentation. Industrial production fell by $20 \%$, and the negative trend that began in the 1980s peaked. In urban development plans, the riverbank has never been considered an integral part of the urban fabric, and a large part of the old industrial zone is today devastated and neglected [66].

\subsection{Industrial Heritage in Belgrade and the Main Challenges}

Preservation of industrial architecture in Serbia is often compromised due to disrespect for their monumental values. Since most of these buildings and sites date from the 18th to the 20th century, they are sometimes not considered old enough to be able to direct the attention of either heritage conservation experts or citizens and users (Figure 6). They do not understand that industrial buildings represent their everyday environment that possess significant monumental values. Although some efforts are being made in Serbia to find a more adequate approach, to modernize legal and administrative systems, to integrate heritage protection into the urban planning process [67] and to achieve greater cooperation between the protection service and the urban institute, it is increasingly difficult to protect the endangered urban heritage, whereas preserving its authenticity and integrity becomes a major professional task. As the preservation of cultural heritage is integrated into laws, with the aim of involving a large number of stakeholders and citizens, in practice, through the process of urban planning, many problems and inconsistencies in the application of these goals can be noticed [68].

Regardless of the situation and neglect, the specific historical and urban identity of the Sava and Danube banks have been preserved to this day. This area is a basic element of the historic cityscape of Belgrade [69], and the banks of the Sava and Danube Rivers are the focus of interest of many planners and investors. The most important area at the confluence of the two rivers is the Belgrade Fortress, a cultural monument of exceptional importance, [70] as well as the area of Kosančicev Venac, a spatial, cultural and historical ensemble of great importance [71].

In order to present the diversity of industrial heritage located on the Belgrade riverfront, we have provided a graphic display of the current state of functional representation of industrial complexes and buildings along the Sava and Danube riverbanks (Figure 7). In our research project, we have included the analyses of the following industrial heritage: an old industrial building called "Beton Hala" ("Concrete Hall”) [61,72], creative district "Savamala" [73,74], the Main Railway Station [64], the building of the State Printing House- "BIGZ" [75], the industrial complex "Old Mill" [74], the Paper Factory of the industrialist Milan Vapa [76], the Belgrade Fair [77], the "Rad" Tool Factory, the Sugar 
Factory [78], the Textile Industry Factory "Beko" [79], the old cargo port of Belgrade, and the old Thermal Power Plant "Snaga i Svetlost" ("Power and Light") [80,81].

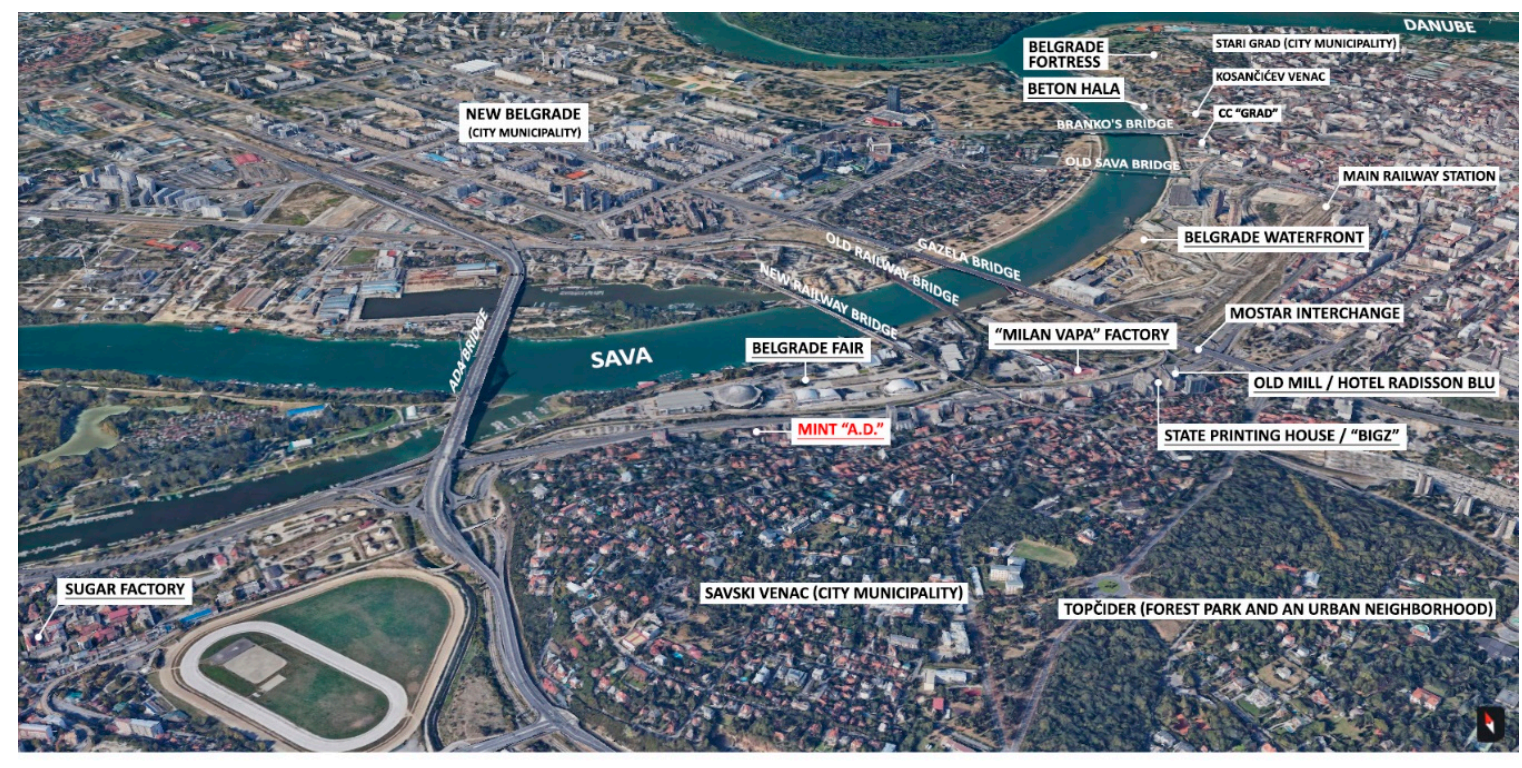

\section{SUGAR FACTORY \\ MINT “A.D.” \\ BELGRADE FAIR \\ "MILAN VAPA" FACTORY}
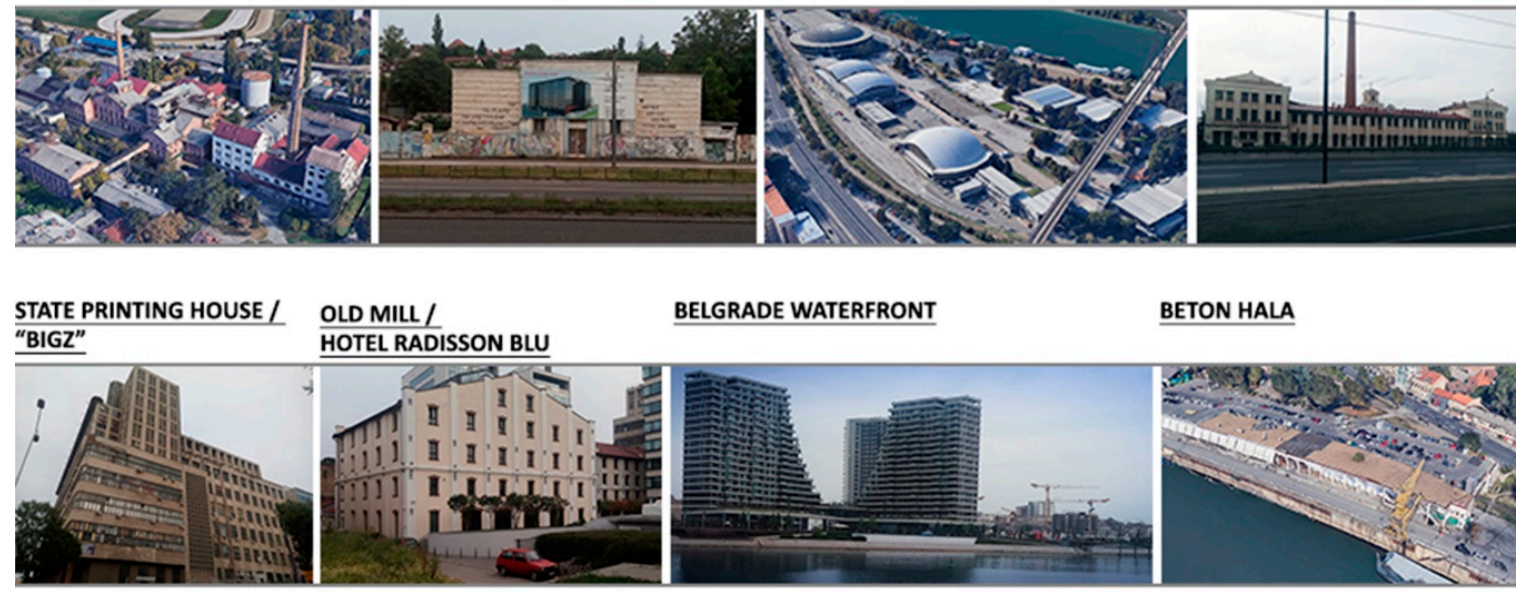

BELGRADE WATERFRONT

BETON HALA

Figure 6. The map of industrial and technical heritage on the bank of the Sava River in Belgrade. Sources: Google Earth (redrawn by authors). The photos of the Sugar factory, the Belgrade Fair and the Beton Hala, Source: Google Earth. Other photos were taken by the authors.

Industrial complexes and buildings located along the Sava and Danube riverbanks, according to the current state of functional representation, can be divided into four groups (Figure 7). The first group consists of complexes and buildings that are in good condition, whose primary function is still active. The largest group consists of complexes and buildings that have been revitalized and whose functions are mainly related to cultural and educational facilities, business and catering. These complexes and buildings have partially preserved their authentic appearance, with certain interventions, in order to adapt to the new purposes. The third group refers to industrial complexes and buildings that are out of primary function and in very poor condition. They are ruined and abandoned, but contain numerous values that should be preserved in future revitalization and presentation projects. The last group consists of complexes and buildings that were demolished in order to build new structures, thus, permanently losing the authenticity and integrity of these units. 


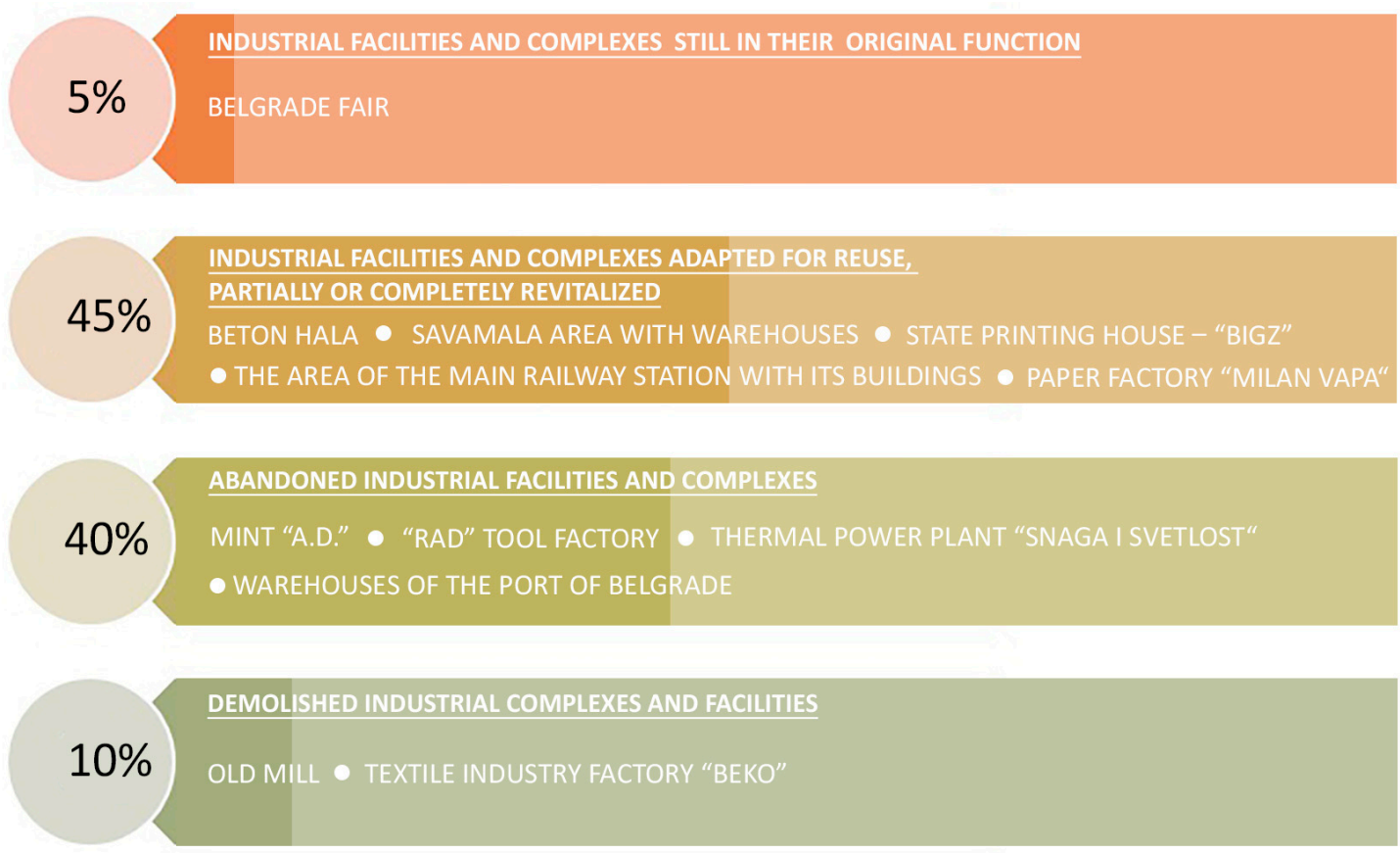

Figure 7. Graphic display of the current state of functional representation of industrial complexes and buildings along the Sava and Danube riverbanks.

\subsection{Environmental and Sustainable Aspects of Adaptive Reuse Approach in Preserving Industrial Cultural Heritage}

The attitude of one of the world's leading architects, Sir Norman Foster, is that an ultimately sustainable building is a building that can be recycled [82]. Instead of demolishing it, the building can be adapted to change. To that end, the great challenge of today's architecture is to be sustainable, to support change, and through modern technologies and techniques to protect and revitalize old buildings, they manage to improve their performance. To this end, Foster and Partners propose a special architecture evaluation method, the Building Research Establishment Environmental Assessment Method (BREEAM), which is widely used in the UK and other countries [83].

The researched case study of the Mint "A.D." is not characterized by high authenticity in an aesthetic and specific architectural style sense, but it is highly authentic in terms of specificity of the natural environment (estuaries, riverbanks of the Sava and Danube, Ada Ciganlija Lake). On the other hand, the built environment is one of the most authentic parts of Belgrade (small fishing cottages on the banks of the Sava and Danube; Belgrade Fortress-the Old Town; the oldest zone of Belgrade-Kosančićev Venac; Belgrade Fair-a miracle of architectural construction technologies from the 1950s, which was declared a cultural monument; as well as numerous industrial facilities in the area). Based on the analysis of the current situation and insight into the General Urban Plan of Belgrade (GUP), the location of Mint "A.D." is not integrated into the planned urban development of the wider area of this zone [84].

When forming adequate solutions for renovation and reuse of the Mint "A.D.", we must keep in mind that the aesthetic appearance and physical condition of the Mint is rather inconspicuous, with very low aesthetic features in terms of architecture. Precisely for this reason, aesthetic and architectural style criteria for the protection of this cultural property are quite low, so protection and preservation should rely on emphasizing the intangible values of this building. It should also be kept in mind that, with industrial buildings in the immediate vicinity, this building participates as an integral and a significant element of the industrial landscape on the urban stretch from Belgrade Fortress to the Ada Ciganlija Lake. 
If the protection and preservation of the Mint "A.D." is viewed from an environmental standpoint as a single entity of the urban industrial landscape within which intangible values are preserved and reuse and renovation are adequately applied, conditions will be created to preserve the authenticity and integrity of this zone. This would save the Mint from a very probable demolition. Therefore, designing an adequate presentation of intangible values of the Mint "A.D.", involving interesting storytelling, manifestations and cultural events, guiding through the exhibition space that will evoke the historical side of the development of industrial production in Belgrade between the two world wars, will create an incentive for adequate reconstruction, aesthetic and visual integrity of the place. Preservation and renovation of the Mint as part of the historic urban landscape fulfills the UNESCO Recommendation on the Historic Urban Landscape by including the Mint "A.D." in the broader urban context and its geographical setting, taking into account the historical layering of cultural and natural values and attributes [85].

Sustainability in terms of culture and architecture as an important domain of culture, in our case study of the Mint "A.D.", is achieved through adaptive reuse. The concept of adaptive reuse of architectural heritage represents a change in the use of exiting construction or structures according to the needs of new or existing owners, with the aim of achieving improvements in environmental, economic and social sustainability [86]. According to some authors, adaptive reuse represents a change in the original purpose of the building, which achieves the goal of gaining space, thus, achieving greater efficiency and cost-effectiveness of the space itself, which receives a new purpose [87]. Thus, urban regeneration prolongs the life of the building and avoids demolition and waste generation, saves the mechanization and energy needed for a new building from the scratch, and also produces numerous social and economic benefits for the community. Industrial heritage can play a very important role in the economic regeneration of decayed or declining areas. Reuse of this heritage may provide psychological stability for the local community [53]. The creative industries contribute greatly to people wellbeing both socially and economically. In addition to economic wellbeing, which is a financial category whose indicators show the level of economic growth, there are also those aspects of valorization of cultural heritage that are difficult to assess economically and fall into the social wellbeing category [88]. Indicators that point to wellbeing provide information on quality of life, happiness, mental health and the fulfillment of certain needs of citizens. Citizen engagement and participation in issues related to the development of their environment greatly improves their wellbeing. Therefore, in architectural heritage reuse and preservation projects, it is of great importance to achieve social fulfillment of human rights and needs, because mental health has a very important role in the achievement of global Sustainable Development Goals [89].

In the work on the preservation and reuse of the Mint "A.D.", we had in mind the Brundtland Report, which views environment and development as two inseparable terms-“environment" as the place where we all live, and "development" as what we all do in an attempt to improve our lot within that abode [90]. We were guided by the idea that sustainability is a "shared territory" because it interacts with diverse stakeholder groups, showing how different interests can be resolved in a compromised way through creative and sustainable solutions [91]. Therefore, the presented projects try to revive the spirit of the place and give it an additional new identity adapted to modern times and needs. As significant experiences, we examined numerous examples from around the world regarding to what extent certain industrial spaces have become the main artistic, cultural, social and tourist meeting points of the city through the use of creative adaptive reuse and creative management [92-96].

It is also very important to pay attention to the preservation of the natural environment of the treated zone, given that the zone where the Mint "A.D." is located is in a natural environment, near rivers, with specific vegetation in the form of low and high greenery. One of the key conditions imposed is the preservation of the natural integrity of the coastal zone. In order to harmonize and sustainably fit into the built and natural environment with the aim of achieving the most adequate, sustainable and high quality of new, preserved and natural assets, the preservation and reuse of the Mint "A.D." should focus on creative methods of conservation, development and inclusion of this 
hitherto non-functional industrial space in the development of a creative city. Applying the concept of creative industries, this research points to new possibilities of the global post-industrial society, which develops on the principles of sustainable economy and environmental sustainable societies, and thus, presents a new cultural basis of the future seen through the unity of economy, production, culture, education and care for the environment for future generations [97].

Environmental Aesthetics and Ethical Positions in Preservation of Architectural Cultural Heritage

Architecture is a complex activity that covers very broad issues from sociological, economic, artistic, technical, technological, aesthetic, ethical, psychological, health, historical to environmental, ecological and sustainable aspects. Most often, priority is given to the aesthetic aspect of architecture, since architecture is a visual art and technical discipline that is perceived through the senses of sight, but also through the perception of the atmosphere in the environment that is built through architecture. It should be noted that the aesthetic role of architecture in the context of environmentalism includes the ethical role of architecture. Ethics of architecture is a very ambivalent discipline that depends on the context and various factors. What we try to emphasize in the valorization of preservation and protection of industrial heritage is focused on ethical issues of the environment from the aspect of social inclusion, natural and economic ethics of the environment which we may characterize as sustainable [98]. In that sense, instead of trying to conquer nature as architecture indisputably does, man should strive to fit architecture into nature, that is, to adapt the construction to the topography and climatic conditions of naturally created environments. In today's world, the economic imperative in architecture has priority. First of all, what is built must meet the requirements of market profitability to the maximum. Economic values are usually in conflict with the symbolic, aesthetic and ethical dimensions of architecture, but in planning and designing in a sustainable way, all these aspects tend to be brought into a reasonable balance. Practical and functionalist requirements of architecture that had priority in the era of modernism and postmodernism even today, must be harmonized with the general and higher goals of environmentalism and sustainability. Architecture needs to be reformed, and that is a new way of architecture in its reevaluation and care for man, which should not, as it often was, stay only on paper-utopia-but should harmonize with the economic imperatives of today. It is about the survival of the human community in the way proposed by the Agenda for Transforming Our World: the 2030 Agenda for Sustainable Development, according to which, architecture should meet the requirements for equality and a healthy environment, sustainable management of natural resources, economic, social and technological prosperity in harmony with nature, for the sake of peaceful, just and inclusive societies in which a solidary partnership of all stakeholders and all people is developed [41].

Therefore, the ethical and aesthetic aspects of architecture must intertwine, as it is necessary to identify the relevant shared values of both these disciplines [99]. Environmental aesthetics and environmental ethics should be positions of significant importance for urban planning, design and protection of architectural and cultural assets and urban units.

Respecting environmental goals, architects and conservators should act and design for sustainable use and reuse of resources. With regard to the protection of large spatial units, it is important to consult Declaration on the Conservation of the Setting of Heritage Structures, Sites and Areas (2005), which prescribes the adequacy of care and management of cultural heritage structures occupying large spatial frameworks (historic cities, landscapes, seascapes, cultural routes, archeological sites), having in mind their protection in the time of accelerated changes and development of townscapes and landscapes [36]. Considering that Belgrade's industrial heritage on the riverfront has a distinctive character that is related to the authentic natural environment located on the banks of rivers and near the historic core of the city, this industrial heritage has a special meaning and historic values. In that context, as a part of the industrial heritage of Belgrade, the Mint "A.D." possesses an authentic spirit of the place, as well as special symbolic and cultural values that represent significant resources for creative, economic and cultural development [39]. 


\subsection{Educational Student Projects of Preservation, Regeneration and Presentation of the Old Mint "A.D."}

3.4.1. Analysis of Cultural and Historical Values of the Mint AD, Its Surroundings and Presentation of the Location in the Strategic Plan of Spatial Development of Belgrade

Mint A.D. is located in the Belgrade municipality of Savski Venac. The municipality of Savski Venac is one of the oldest municipalities in Belgrade, as its coastal parts were the first urban tissues. When the first Serbian prince Miloš Obrenović (1780-1860) settled in Topčider, a part of the city municipality of Savski Venac, in the 19th century, it was obvious that Belgrade would develop in that direction [100]. With the establishment of this social construction, many first things in Belgrade appeared in Savski Venac, namely the first hospitals, the first tram lines, the first theaters, cafés and markets and the first ministry [100]. In the area of the municipality of Savski Venac, there are some of the most important cultural institutions of the society, such as the Yugoslav Drama Theater, Student Cultural Center, scientific and social institutions such as the Palace of Justice and the main facilities of court infrastructure, a cultural monument-the State Printing House- "BIGZ", commercial facilities such as the Belgrade Beer Industry, the Banknote Production Institute, and numerous hotels and restaurants. The proximity of natural resorts, Topčider and Košutnjak, as well as good connections with other parts of the city, are important for the possibility of reviving important facilities and connecting with significant historical areas which are located there, the revitalization of which would contribute to the cultural development of the city and its revival [100].

During the Kingdom of Yugoslavia (1918-1945), a predominant part of the housing stock of the settlement was built in this part of the city, and many Yugoslav post-war architects took an individual part in shaping this part of the city [101].

The Mint "A.D.", which is located on Bulevar Vojvode Mišića Street, has a good connection with the other side of the river, because it is located between two bridges-one is the "Bridge on Ada" and the other is the "Gazela" bridge. Bulevar Vojvode Mišića Street continues to Savska Street, which is a connection with the old part of the city with the center in Knez Mihailova Street. The area of Mostar interchange and Bulevar Vojvode Mišića are important areas of Belgrade. The Mostar interchange began to disappear with the construction of the modern Bulevar Vojvode Mišića Street, then the large complex of the Belgrade Fair and finally, the construction of the "Gazela" bridge in 1968-1970, which brought the highway to the city along with noise, smog and pollution [58].

As opposed to the cultural-historical context, there is the current planning strategic framework-General Urban Plan of Belgrade. The General Urban Plan of Belgrade (GUP) is the main urban plan that implements protocols and procedures and plans the effects of city development by contextualizing urban-architectural practice within institutions, society and everyday life.

The morphological peculiarity of the spatial whole of the city municipality of Savski Venac determined this space for specific purposes-family and residential housing. The General Plan of Belgrade notes that this whole area is characterized by a large number of architectural works that have been declared cultural goods or enjoyed previous protection. There is the presence of clinical and hospital institutions and large landscaped park and forest areas, of which the Topčider complex is protected as a cultural asset of exceptional importance. In that whole area, certain tree lines and individual trees are protected as natural monuments. According to the General Urban Plan, the largest part of this whole area is defined as a permanent asset of Belgrade and as such, is unique for the city. Parameters of a high degree of protection and ambient integrity mark all future interventions and activities in this area [84].

According to the General Urban Plan of Belgrade, parts of the municipality of Savski Venac (among which, Bulevar Vojvode Mišića Street is mentioned) represent an area where a large number of cultural goods and units that enjoy protection are concentrated. In this regard, a "general renovation" is envisaged for this area, which implies the application of integrative conservation, urban renewal and spatial planning, which is harmonized according to the scope and new value of architectural heritage [84]. 


\subsubsection{Results of the Educational Projects for the Revitalization of the Old Mint "A.D."}

The architect of the Mint "A.D." (Figure 8) is Bogdan Nestorović (1901-1975, Belgrade), a Serbian architect, author of several books on the history of architecture and a university professor. During his long and fruitful career, he designed some of the most important buildings, such as: the Craft Home (1931-1933, today Radio Belgrade), the Privileged Export Joint Stock Company (1938, today the Tanjug building), the Cathedral of St. Sava with prof. arch. Aleksandar Deroko (1926-1927). He is the author of a large number of professional papers and books, ranging from general to national history of architecture, some of the most important being the following: Architecture of the Old Century (1952), Architecture of the New Century (1964) and Architecture of Serbia in the 19th Century (published in 2006). In 1971, he received the Lifetime Achievement Award [101].
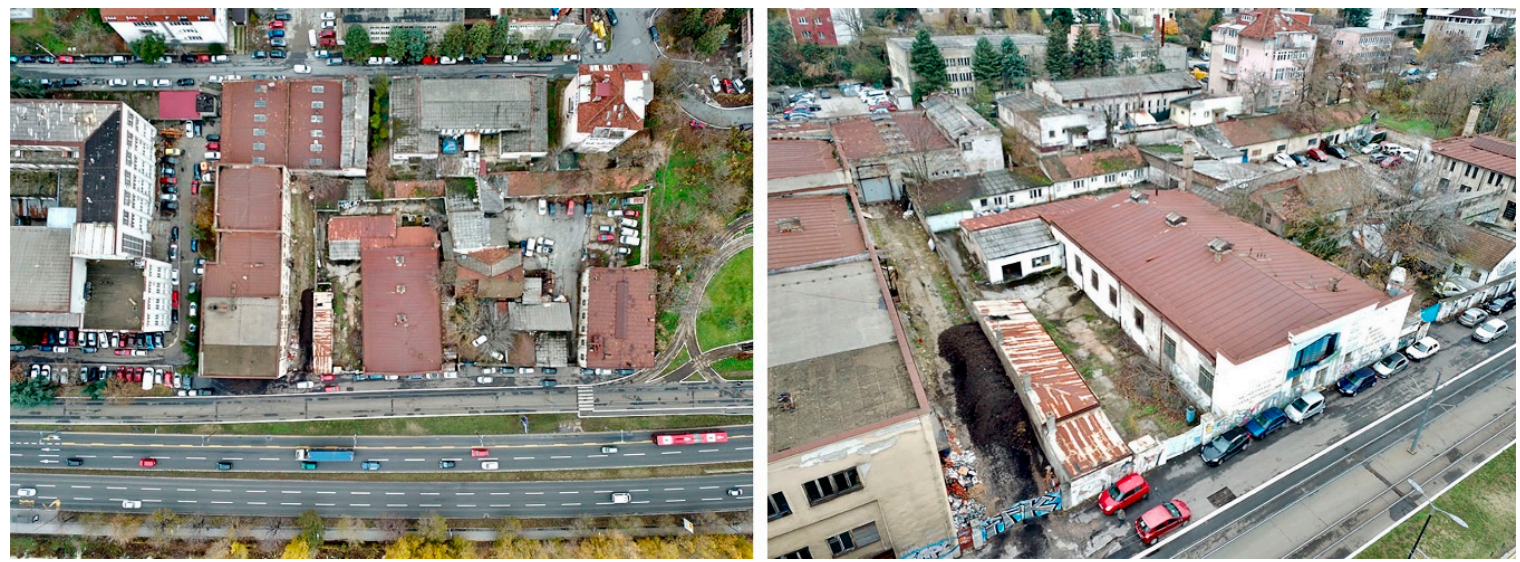

Figure 8. Drone view of the mint “A.D.” (photo: student Radojević Marko).

After the conditions for the construction of the Mint "A.D." were met, in 1930, a joint stock company erected the Mint building at 43 Bulevar Vojvode Mišića Street. The building was designed in the modern spirit that Bogdan Nestorović applied to his other buildings from this period [102].

The Mint "A.D." is dominated by the central corridor leading to all rooms within the building. After passing through the part with auxiliary and administrative premises, you enter the part of the production facility that extends from the left and right side of the corridor all the way to the economic entrance in the south (Figure 9).
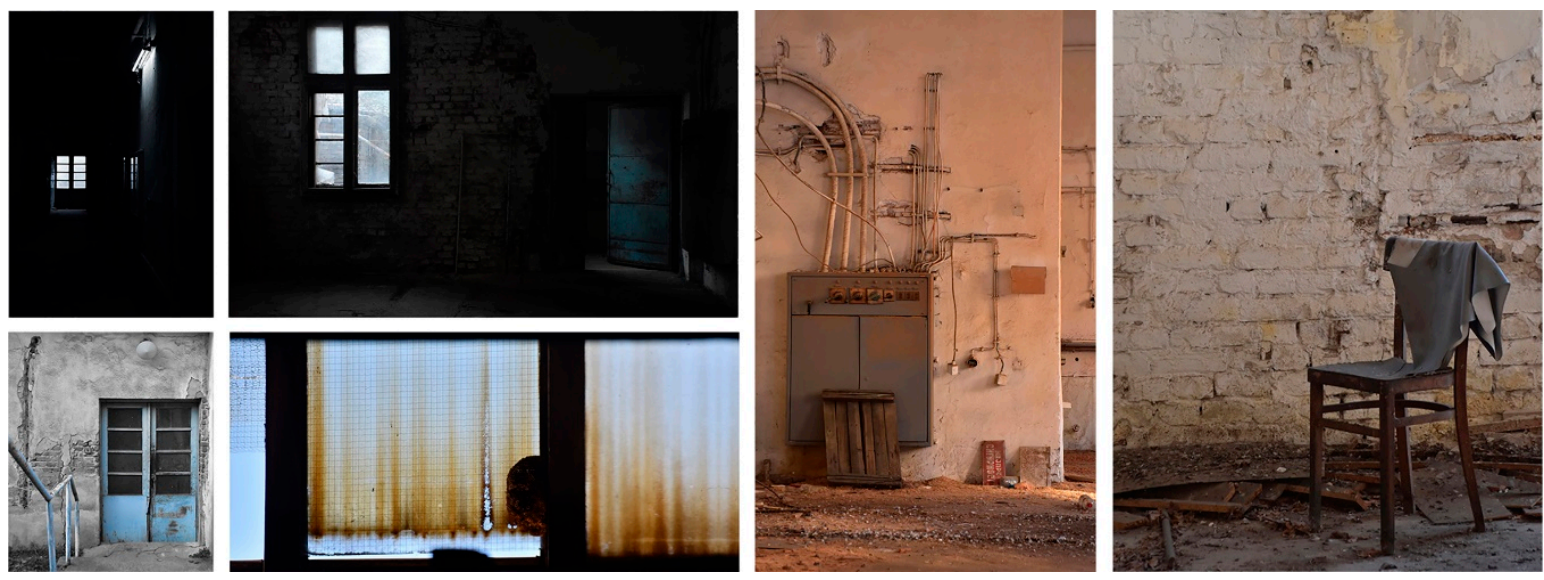

Figure 9. Current interior condition of the mint "A.D." (photos: students Petrović Nevena, Jeremić Teodora, Radenković Emilija and Jovančević Milica).

The students analyzed the available technical documentation and it was determined that the building was built in a masonry construction and system of load-bearing longitudinal walls. The primary 
materials used in the construction are brick and concrete. As an adequate support, strip foundations without a basement were formed. The roof is made of wood with a king post roof truss.

Several buildings can be recognized on the building plot, which were created later in the service of the main building. Access to the main building is provided from Bulevar Vojvode Mišića Street through the main entrance, or economically through the courtyard. Inside the courtyard, in addition to the guard building which is drawn in the plans, there are annexes on the building, as an extension of the main room, which bears the purpose of a mint. In addition to these two facilities, additional rooms were built at the bottom, which served as offices and workshops for the later purpose of this building, the public metal company "Titan".

\section{Review of Student Projects}

Group 1-The Educational Museum Project originated from the intention to form a new modern museum space with maximum preservation of the architectural heritage, along with spaces intended for education, both for children and other citizens and tourists (Figure 10).

The interior space has been adapted to the future function through the planning of various facilities, namely workshops, gardens, galleries, souvenir shops and cafés, which would further lead to a permanent outdoor exhibition. Light and transparent materials would be a replacement for a large part of solid walls. By replacing the internal massive walls with a glass surface, direct communication of the observers with the exhibits is established.

A gallery is planned that would be completely passable and useful. The new steel roof structure was raised to a higher height, which created a pleasant ambience of the gallery, becoming a multifunctional space with variable purposes. The proposal is to organize lectures and workshops on this floor, where visitors would be introduced to the history, functioning and process of making money that took place at the mint.

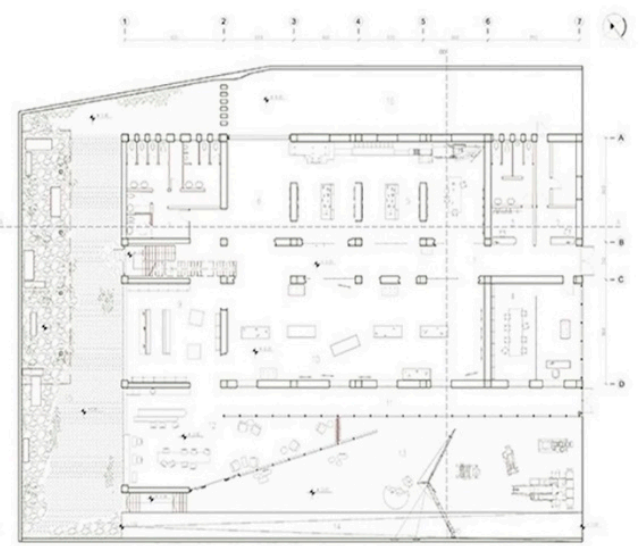

a

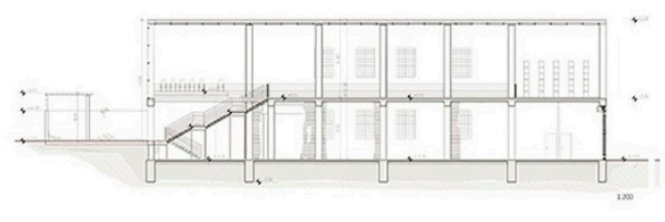

b

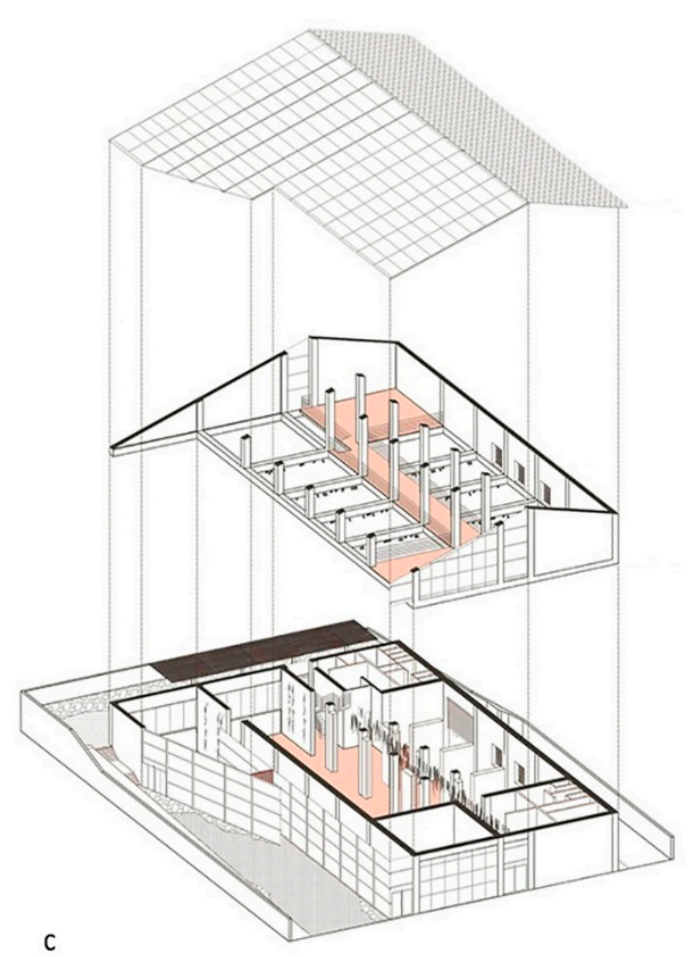

C

Figure 10. (a) Floor plan; (b) Section; (c) Exploded axonometric of the revitalized condition of the mint “A.D." (authors: students Vićentijević Vanja, Luković Mila, Plećević Tamara and Ristić Milena). 
There is a direct exit from the museum space to the inner garden. The idea is that the garden contains a space for rest, regarding which a pergola is planned in the area of the garden and where urban furniture is also planned. In the other part of the yard, there is an attractive exhibition of permanent exhibits, which includes machines that are no longer in function.

In order to preserve the value of the original building, which is an important element in the approach to the revitalization of industrial buildings, the project seeks to preserve the original facade of the mint as well as the preservation of machines that participated in production. The goal was to preserve the original appearance of the factory with changes in floor height, roof construction and hollowing out of the facade for the purpose of additional lighting. In order to emphasize the old facade and enclose the expanded space, the project envisages a curtain wall in the form of a "double facade".

In addition to tourists, the largest target group would be children and young people, whose awareness of the importance of industrial architectural heritage is increased through lectures and interactive workshops.

Group 2-The project of a modern theater as the primary carrier of revitalization of this project originated due to the significant height of the building (about $5 \mathrm{~m}$ ) and its spaciousness. With the aim of achieving a greater degree of ambience, scenicity was identified as a key character in forming future identity (Figure 11).

Spatial reorganization would to some extent preserve the original organizational scheme of the building. It is envisaged that the main corridor, which is the main carrier of the spatial organization, would retain its primary communication function, and, along with the foyer, it would become part of the exhibition and gain not only a communication, but also an educational character.

In other words, the foyer has the primary task of accepting the audience for the upcoming show, and along the way, introducing them to the history of the mint through archival photographs (in the form of an exhibition space) as well as video projections/holograms that testify to the way man tempered his identity through the minting process. A support for this program is the gallery space (existing), which provides additional information to users about coins, medallions and other representative objects of numismatic association. The former premises of the workshop are united in one large room, which is given the function of a theater. A ballet and stage rehearsal hall is planned for the new purpose of the smelter.

The spatial capacity is expanded by adding an open-air amphitheater that is connected to the building by a passage.

Within the base of the floor, there is a gallery above the foyer, which is intended for sitting and also forms part of the educational zone. In the room with the stage, a gallery space is added, which is intended as a multimedia space. At the same time, parallel to the rear facade of the building, there are workshops for costumes and scenography in the form of annexes.

The intervention in the construction was first reflected in the replacement of the massive wall of the corridor with pillars, which led to the opening of space for the purpose of exhibition and education. In order to form the theater stage and accompanying rooms, the partition walls of the mint's working spaces were demolished, which resulted in one larger room.

The roof structure has been completely replaced by a steel structure, with the addition of a lantern above the foyer. The construction of the newly created gallery above the foyer consists of a combined ceiling with steel steps. At the external annex to the building, a glass narthex has been added, which allows part of the space to be used in winter as well.

The main change that characterizes this spatial intervention refers to the hollowing of the wall that forms the central horizontal communication, and the introduction of a series of pillars. The intention that established such a spatial treatment was to integrate the recognized longitudinality with the lateral segment, while forming the cooperation of the educational and exhibition zone.

The original facade of the building has been completely preserved with the necessary repairs. Brick is the main material used. The roof covering is galvanized sheet metal. The windows were also 
retained with the necessary repairs. A glass annex was formed on the south facade, which is intended for a costume design workshop.
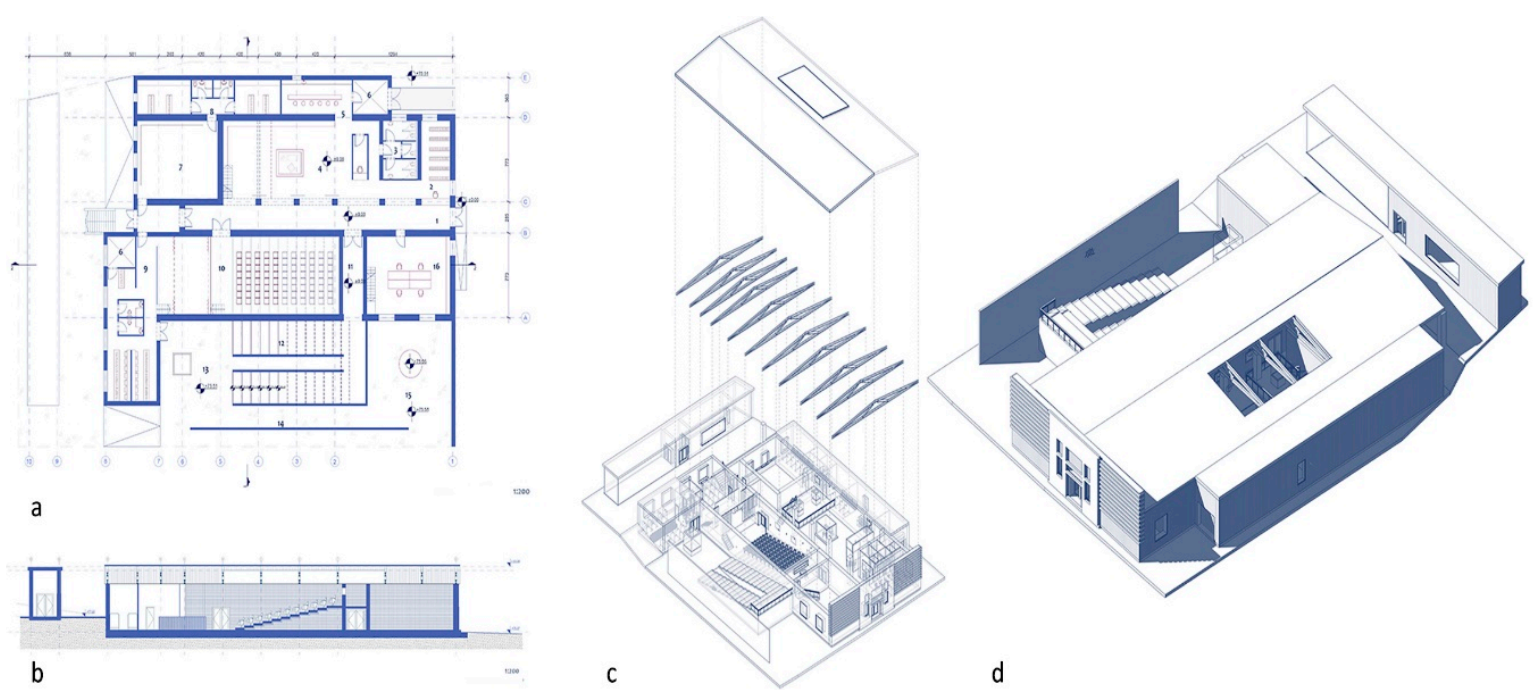

Figure 11. (a) Floor plan; (b) Section; (c) Exploded axonometric; (d) 3D model of the revitalized condition of the mint "A.D." (authors: students Petrović Nevena, Jeremić Teodora, Radenković Emilija and Jovančević Milica).

Group 3-The basic idea of this project is the revitalization of the old mint building into a cultural and catering space (Figure 12). The position of the main communication corridor has been retained on the ground floor, with cultural and catering facilities added on the left and right sides. The visual identity of the main corridor should point out to the visitors the historical significance of the mint through the exhibition part that is located in it. That part of the building is actually an introduction to an even larger exhibition space that is separated from the hall by movable walls. On the other side of the hall, workshops are planned, where visitors will have the opportunity to get acquainted with the way of making old crafts through expert guidance. Additionally, on the ground floor, there is a catering space, a sanitary part and offices. The base of the gallery is intended exclusively for visitors and contains a library and a space for sitting and reading.
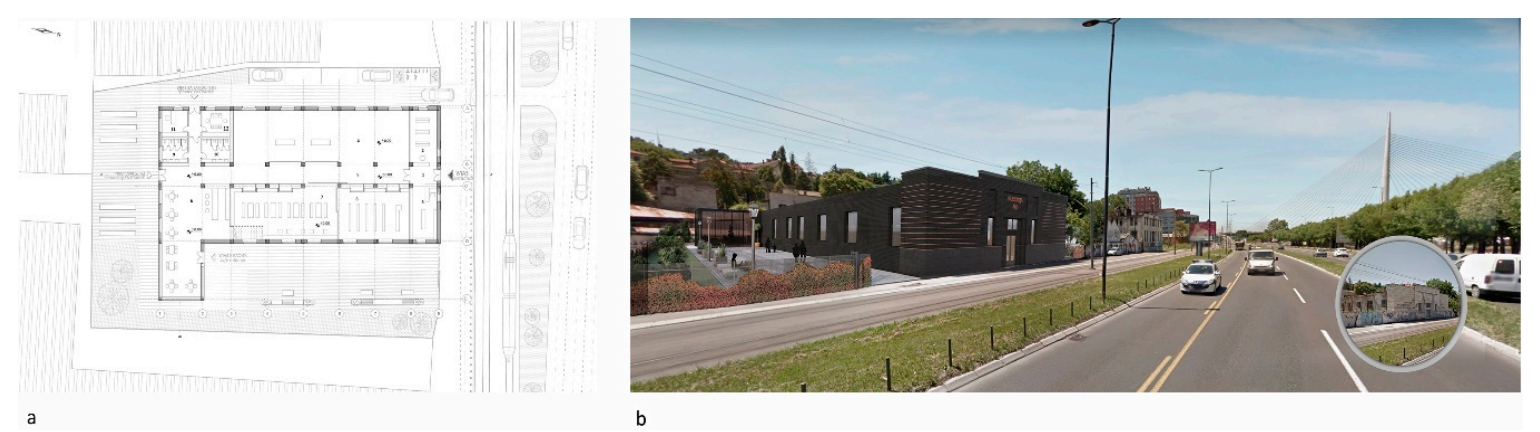

Figure 12. (a) Urbanistic situation/Floor plan; (b) Depiction of the revitalized condition of the mint “A.D." (authors: students Savić Mima, Benić Ksenija, Bogunović Danica and Radojević Marko).

In the construction of the building, the aim was to keep it as much as possible even after the revitalization for the sake of authenticity and to increase the visual attractiveness of the space itself. This retained the entire structure, which consists of a system of concrete pillars and beams, as well as all internal load-bearing walls with brick infill. Partition walls have been completely removed in many places, while in some parts, they have been replaced by prefabricated or movable walls, which can be moved depending on the function to be performed in a certain part of the building. The roof 
structure has been renovated with a steel grid construction, which lies on the basic structure of the building-concrete pillars-and supports the roof. In that way, the load is transferred from the roof to the steel grid, and then, it is transferred to the concrete foundations of the building through concrete pillars and walls.

The facade itself remained unchanged in shape, as did all the openings, including the doors and windows. What makes this space stand out, among other things, is the visual treatment of its surfaces. Namely, by looking at the history and function of the building, that is, the fact that industrial activity was performed in this building, it led to the idea of a black facade of the building. Then, in the interior, a contrast was made in colors, black and white (Figure 13). In terms of materialization, all materials used in the construction of the original building were retained, and during the revitalization of the building, the walls retained concrete pillars and brick infill. The roof structure has been renovated with steel grids that are visible and especially contribute to the appearance of the entire space. A small part of the building was demolished and modernized with glass walls that enable better lighting of part of the interior space and transparent reading of the spatial organization.
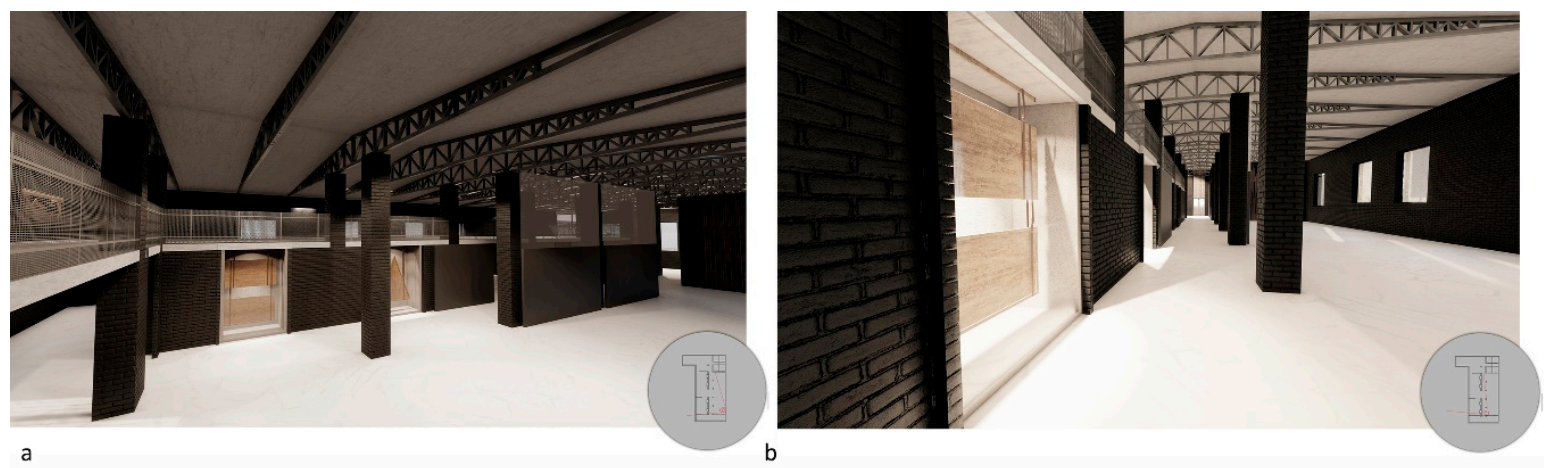

Figure 13. (a) Interior model 1; (b) Interior model 2 (authors: students Savić Mima, Benić Ksenija, Bogunović Danica and Radojević Marko).

Group 4-In terms of revitalization, this project was guided by the idea of creating an interactive exhibition space (Figure 14). The basic idea is that, in addition to exhibition activities, the space also includes various film, art, theater projections, performing arts and debates. The project proposes the removal of partition walls and the opening of space. In that way, the functions were networked, and the impression of a larger and more spacious interior was created.

The project envisages a gallery at elevation +2.50 from the level of the finished ground floor, which received an administrative function and is connected to the courtyard of the building by an external spiral staircase at the back of the building and to the ground floor by a steel interior staircase. In the gallery itself, an administrative block is planned in the form of open office spaces that can be separated by a glass accordion partition from the rest of the floor (toilet, kitchenette and terrace), from which you can also access the floor, climbing the steel spiral staircase from the courtyard.

The part of the building below the gallery is intended for projections and presentations and is separated from the exhibition space by glass panels, which also enables communication and interaction between functions, while the glass facade is open to the courtyard and thus, enables view of greenery from the entire interior. As part of the new functions, there is also a café with a garden that is visually separated from the street and the rest of the yard, while the auxiliary building has been turned into a retail space.

The yard space is resolved with green areas and paved paths that lead to the parking space and the rear entrance to the building. The idea to achieve the best possible connection between the interior and the yard is achieved by enabling access to the outside space by using the main entrance to the building and courtyard entrances, which enables direct contact with the environment.

The project largely retains the facade according to the existing condition, while the courtyard facade has been changed in accordance with the concept. The street facade is mostly kept in its current 
condition. In the zone of the fence, on the left side in relation to the main entrance to the building, there is a green wall, that is, the greenery that enriches the space and emphasizes the entrance zone to the courtyard. In this way, the facility is in touch with nature and greenery. The courtyard facade suggested a new purpose of the space by installing a curtain wall that can be opened in the warmer part of the year and enable easier movement through the exhibition space. Since the massive facade walls in most of the building were kept in their original condition, the window openings are also there. The side facade is enriched by placing higher and wider openings in order to let as much light as possible into the interior of the building, which gives an additional contribution to its ambience.

The materialization of the facade was maintained in accordance with the existing condition, which is in the lower zone of the front facade with the finishing of plaster and stone slabs.

According to the project, the ambient connection of indoor and outdoor space was designed by introducing a water surface that suggests flow and connecting functions. Thus, better communication in the space was achieved.
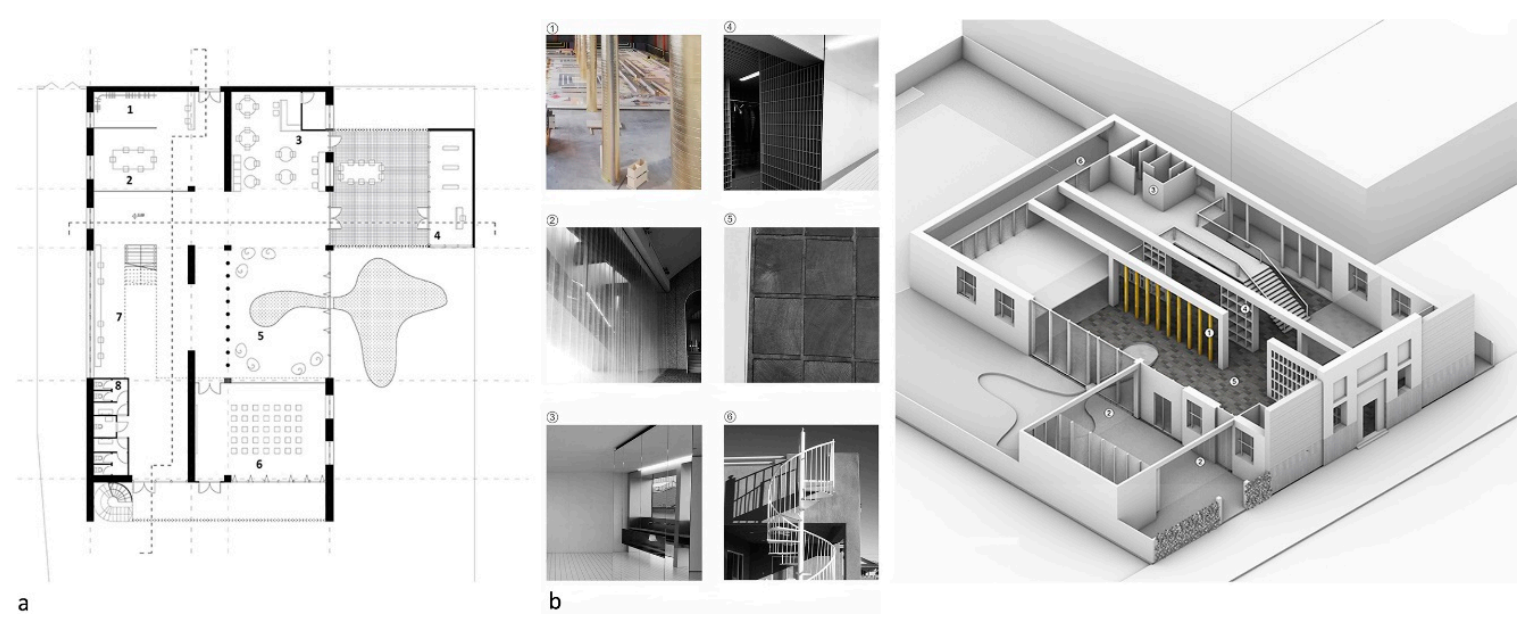

Figure 14. (a) Floor plan; (b) Materialization and axonometric of the revitalized condition of the mint "A.D." (authors: students Stevanović Mia, Stojković Marija and Ašković Nevena).

Group 5-The concept of the Mint revitalization project is to give a new character to the building and transform it into a new mini center of culture and education (Figure 15). The base is divided into two key parts by a corridor, as a central communication space. The western part is intended for the restaurant, administration and employees, and the economic space that is connected to the underground floor, which has the function of a warehouse. The eastern part is intended for educational content, and it houses a museum, a library, an exhibition of the history of the site and a flexible space for lectures. That part of the building is directly connected to the garden, through cracks in the facade that reduce the barrier between the interior and exterior space.
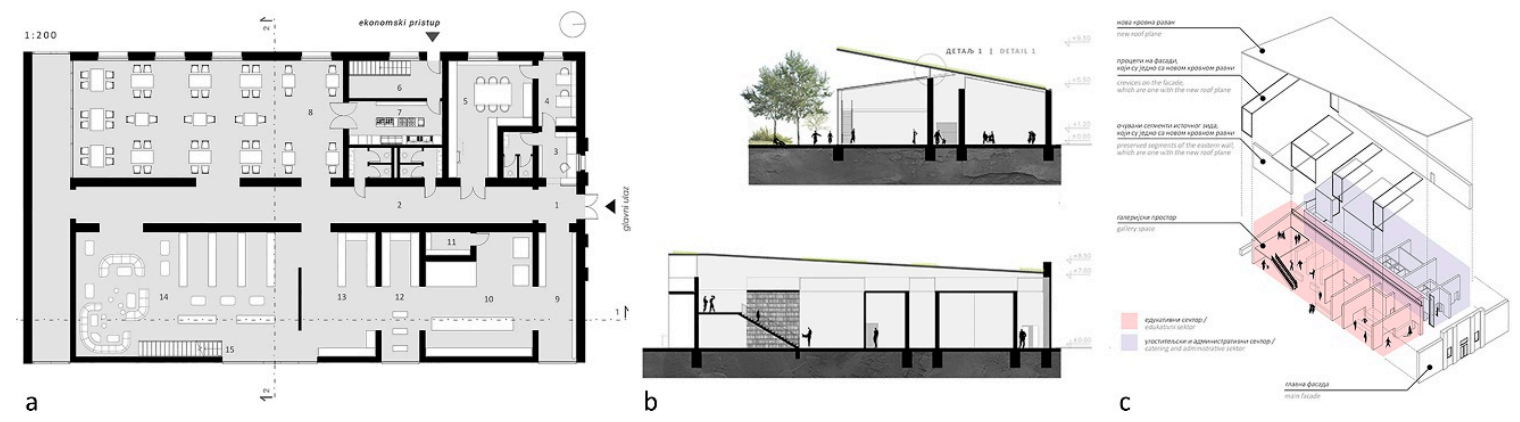

Figure 15. (a) Floor; (b) Sections; (c) Axonometric depict of the revitalized condition of the mint "A.D." (authors: Korica Una, Ćirić Teodora and Ćesarević Sara). 
Using new functions, such as a museum and a modern library, meet the need for this content in this part of the city. The smaller, accompanying building of the Mint "A.D.", which once served as a space for the keeper, was also repurposed in accordance with the whole concept and given the function of a private greenhouse. Equally, through function and form, the conversion is read by dividing it into existing and new structure, and on the courtyard facade itself, the division in the interior and the functions inside is read.

By looking at the axonometric view, the individual interventions performed on the facility are best noticed. Primarily separating the planes of the gable roof and placing them in a new relation, so that they pass each other, one roof plane merges with the facade plane, which overlooks the courtyard space, and the openings from the facade extend to the roof. On the other hand, the second one was turned into a single roof cover, which, following the geometry of the second plane, was divided into green parts and parts with solar panels.

The new gable roof becomes an element, one side of which connects with the mentioned facade and forms a structural element that follows its shape and division into transparent and full, and this connection is transferred all the way to the ground floor. The second side of the roof, with a different slope, covers the building and the first side, thus forming a canopy for the new gallery space in the southern part of the building. The principles of sustainable architecture are implemented in the roof in the form of solar panels that provide a renewable energy source for the entire building, together with a green layer that performs the function of thermal insulation, and compensates for energy consumption due to large glass openings.

The new roof design solution enabled its higher height and higher usability of space, primarily by introducing a gallery floor that provides additional quality to the library/reading room ambience, but at the same time and functionally, provides additional space where lectures, group discussions or other similar activities can be held. At the same time, the cross-sections read the way in which two typologically different roof elements meet and the gap that occurs in the interspace. The gap contributes to the solution of the lack of light in the space by becoming a lantern.

Parts of the roof on which solar panels are not mounted contain a layer of greenery as another form of energy saving. According to some researchers, by reducing the roof temperature, the amount of heat that is transferred to the outside air decreases. This would result in areas with lower air temperatures slowing down urban smog formation and improving human health. Reducing the roof temperature can also extend the life of the roof itself by reducing the heat wave [103]. Further studies show that increasing the reflectivity of the surface and increasing the vegetative cover have approximately the same cooling effect. Green roof infrastructure can reduce average temperature areas in a city, averaging about $1.4^{\circ} \mathrm{C}$ if 50 percent of flat roofs are greened. This contributes to the fact that green roofs can improve air levels and human health [104]. Green roofs can save energy needed to cool and heat the building they are in, and they can also reduce energy demand and thus, greenhouse gas emissions; green roof infrastructure can reduce average temperature fluctuations in the city. In addition to reducing the heat island effect, green roofs can improve air levels and human health. Some authors point to the importance of green infrastructure as an integral part of the sustainable development strategy, focusing on green infrastructure protocols and procedures in Belgrade [105].

Students came to form this approach to sustainable architecture through lectures, studying the literature and researching examples of good practice in the world. The presented solution shows the shape of the roof, which gives the impression of merging two different structures and gives a new identity to this building, making: (a) contrast to the historical integrity of the industrial landscape, (b) harmonization of modern adaptation with the surrounding coastal landscape (Figure 16). This increases the attractiveness of the place with respect for this historic building and the authenticity of the coastal part, with the possibility that this approach could be a guideline for planners and architects in all future revitalization and presentation projects in the coastal area and beyond. 


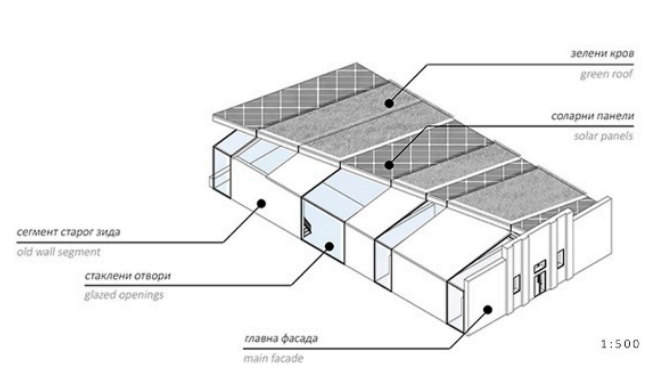

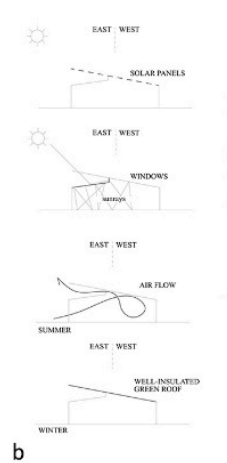

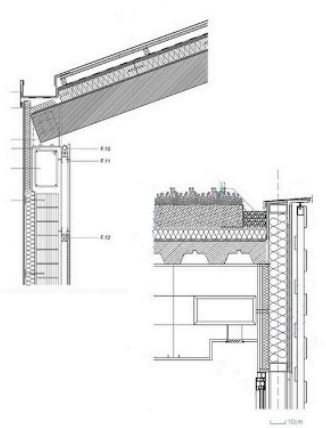

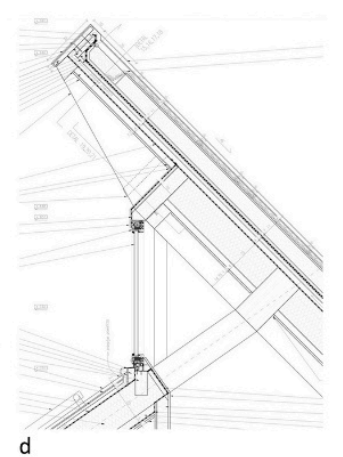

Figure 16. (a) Axonometric view with materialization; (b) Diagram of the characteristics of the solar panel; (c) Detail of hidden gutter and detail of a green roof; (d) Detail 1 (authors: Korica Una, Ćirić Teodora and Ćesarević Sara).

The division of the facade and the roof conditions the interior space, so that it is functionally divided into two sectors-educational and administrative with catering. Within the educational sector, the content is also divided to follow the division on the facade, and here, we recognize the library as the most dominant space, and then, the museum with a souvenir shop and exhibition space.

New transparent fields have been formed by gaps on the east facade, and the original parts of the existing wall match them. That facade underwent major intervention, due to the opening of the space towards the yard and additional lighting of the space, which in the past, received daylight through the window openings.

In this way, it is physically connected to the outer space, which was not the case before. The back facade, towards the courtyard, is also glazed in the restaurant area. The existing exit has been preserved, as well as the rest of the former back wall, which now has an archeological function and tells us about the original building. The main street facade is completely preserved.

\section{Discussion}

Forgotten industrial facilities are good training grounds for the development of various cultural and artistic contents that enrich society itself. The Mint "A.D." is located in the central part of the city of Belgrade, in a zone rich in industrial heritage and represents an adequate place for the development of various activities that would, again, draw attention to this neglected example of industrial cultural heritage. Based on the conducted analyses of the Mint "A.D.", the students concluded that their solutions should be formed in accordance with modern needs that present the historical development and production process of this complex. By forming such an approach, students pointed out the importance of presenting tangible and intangible values, which contributes to preserving the authenticity and integrity of the complex. With their solutions, the students tried to keep the primary cultural and educational character of the complex through reactivation of the complex, with new artistic, educational and catering contents, and thus, make it more attractive for visitors. By carefully choosing new activities, the students breathed new life into this important example of Belgrade's industrial heritage. Through their projects of protection, revitalization and presentation of the Mint "A.D." complex, students envisioned small or partial changes in the spatial organization of the building, construction and design of facades, thus, following the basic principles of protection of architectural heritage based on preserving the authenticity and integrity of a historic site. They retained the basic spatial and organizational structure of the building, as well as significant stylistic elements on the facades. In their projects, the students paid special attention to emphasizing and using important elements that make this space sustainable and cost-effective, with the use of natural materials, which are compatible with the existing materials. Through their projects, they also strived to preserve the elements of intangible heritage through various workshops, artistic and educational events which 
would revive old crafts, customs and the like, and bring them closer to the citizens-the future users of this space (Figure 17).

Belgrade, as the capital and cultural center of Serbia and the former Yugoslavia, was an important industrial center during the 19th and 20th centuries. Therefore, recognizing the role and researching the industrial heritage of Belgrade is a very important undertaking primarily in terms of affirmation and positioning of this specific type of heritage in the context of general national culture. With this in mind, the teaching activities carried out at the Faculty of Architecture in Belgrade, scientific research and final projects of the presentation, conservation and revitalization of the industrial facility Mint "A.D." have a special significance contributing to the diversity of Belgrade's cultural identity. In particular, by drawing the public's attention to the creative proposals, the given reuse of the Mint "A.D." and the areas around it additionally contributes to the richness of various contents of Belgrade as one of the very current tourist centers in Europe, whose number of tourists has been constantly increasing in recent years.

Attractive and fresh educational student projects of conservation and revitalization of the Mint "A.D." contribute to the initiative to eliminate the common opinion of city authorities, the public and the local community, that abandoned and obsolete industrial facilities in the city center should be eliminated because they are an example of ugly aesthetics that distort the beauty of the space that is usually planned as architecture built from the scratch, i.e., without any restrictions for new construction. Conducting research of this type at the Faculty of Architecture in Belgrade educates young people, who in the future, will be the bearers of advanced and sustainable initiatives. Public presentation of project solutions informs the public about the potential of reuse and conservation of industrial spaces as an important element in preserving the city's history, as well as in creating a new contemporary identity that is a driver of economic, social, cultural and tourism development.

\begin{tabular}{|c|c|c|c|c|c|c|c|c|c|}
\hline & $\begin{array}{l}\text { Proposal of the } \\
\text { content of new } \\
\text { purposes of the } \\
\text { complex }\end{array}$ & $\begin{array}{l}\text { Monumental } \\
\text { values that are } \\
\text { emphasized } \\
\text { and preserved } \\
\text { in the } \\
\text { proposals }\end{array}$ & $\begin{array}{c}\text { Degree of } \\
\text { preservation of } \\
\text { the original } \\
\text { spatial } \\
\text { organization in } \\
\text { the proposals }\end{array}$ & $\begin{array}{l}\text { Degrees of } \\
\text { preservation } \\
\text { of the original } \\
\text { construction } \\
\text { and assembly } \\
\text { in the } \\
\text { proposals }\end{array}$ & $\begin{array}{l}\text { Degrees of } \\
\text { preservation } \\
\text { of original } \\
\text { stylistic } \\
\text { elements on } \\
\text { the facade in } \\
\text { the proposals }\end{array}$ & $\begin{array}{l}\text { New applied } \\
\text { materials in } \\
\text { architecture } \\
\text { design in } \\
\text { proposals }\end{array}$ & $\begin{array}{l}\text { Elements of } \\
\text { sustainability in } \\
\text { the proposals for } \\
\text { protection, } \\
\text { revitalization and } \\
\text { presentation of } \\
\text { the complex }\end{array}$ & $\begin{array}{l}\text { Intangible } \\
\text { heritage in the } \\
\text { function of } \\
\text { revitalization } \\
\text { and } \\
\text { presentation }\end{array}$ & $\begin{array}{l}\text { Cost- } \\
\text { effectiveness } \\
\text { and } \\
\text { sustainability of } \\
\text { new proposals }\end{array}$ \\
\hline $\begin{array}{l}\text { Group } \\
01\end{array}$ & $\begin{array}{l}\text { Museum; } \\
\text { workshop space; } \\
\text { café; } \\
\text { administration }\end{array}$ & $\begin{array}{l}\text { Historical; } \\
\text { urban; } \\
\text { architectural; } \\
\text { memorial; } \\
\text { technical; craft }\end{array}$ & $\begin{array}{l}\text { Partially } \\
\text { preserved }\end{array}$ & $\begin{array}{l}\text { Partially } \\
\text { preserved }\end{array}$ & $\begin{array}{l}\text { Largely } \\
\text { preserved }\end{array}$ & $\begin{array}{l}\text { Lightweight/ } \\
\text { transparent } \\
\text { materials; } \\
\text { glass surfaces }\end{array}$ & $\begin{array}{l}\text { Use of local } \\
\text { construction } \\
\text { materials; urban } \\
\text { green spaces }\end{array}$ & $\begin{array}{l}\text { Workshops; } \\
\text { Traditional } \\
\text { craftsmanship; }\end{array}$ & $\begin{array}{l}\text { High } \\
\text { convenience }\end{array}$ \\
\hline $\begin{array}{l}\text { Group } \\
02\end{array}$ & $\begin{array}{l}\text { Theater; } \\
\text { exhibition space; } \\
\text { outdoor } \\
\text { amphitheater; } \\
\text { café; admin. }\end{array}$ & $\begin{array}{l}\text { Historical; } \\
\text { architectural; } \\
\text { memorial }\end{array}$ & $\begin{array}{l}\text { Largely } \\
\text { preserved }\end{array}$ & $\begin{array}{l}\text { Partially } \\
\text { preserved }\end{array}$ & $\begin{array}{l}\text { Largely } \\
\text { preserved }\end{array}$ & $\begin{array}{l}\text { Steel } \\
\text { construction; } \\
\text { glass surfaces; } \\
\text { locally made } \\
\text { bricks. }\end{array}$ & $\begin{array}{l}\text { Use of local } \\
\text { construction } \\
\text { materials; }\end{array}$ & $\begin{array}{l}\text { Performing } \\
\text { arts; } \\
\text { Workshops; }\end{array}$ & $\begin{array}{l}\text { High } \\
\text { convenience }\end{array}$ \\
\hline $\begin{array}{l}\text { Group } \\
03\end{array}$ & $\begin{array}{l}\text { Library; } \\
\text { showroom; } \\
\text { workshop space; } \\
\text { projection hall; } \\
\text { café; admin. }\end{array}$ & $\begin{array}{l}\text { Historical; } \\
\text { architectural; } \\
\text { memorial; }\end{array}$ & $\begin{array}{l}\text { Partially } \\
\text { preserved }\end{array}$ & $\begin{array}{l}\text { Largely } \\
\text { preserved }\end{array}$ & $\begin{array}{l}\text { Largely } \\
\text { preserved }\end{array}$ & $\begin{array}{l}\text { Lightweight/ } \\
\text { transparent } \\
\text { materials; } \\
\text { movable walls; } \\
\text { glass surfaces }\end{array}$ & $\begin{array}{l}\text { Use of local } \\
\text { construction } \\
\text { materials; }\end{array}$ & $\begin{array}{l}\text { Workshops; } \\
\text { Social } \\
\text { practices; }\end{array}$ & $\begin{array}{l}\text { High } \\
\text { convenience }\end{array}$ \\
\hline $\begin{array}{l}\text { Group } \\
04\end{array}$ & $\begin{array}{l}\text { Interactive and } \\
\text { exhibition space; } \\
\text { café; } \\
\text { administration }\end{array}$ & $\begin{array}{l}\text { Historical; } \\
\text { urban; } \\
\text { architectural; } \\
\text { memorial; }\end{array}$ & $\begin{array}{l}\text { Partially } \\
\text { preserved }\end{array}$ & $\begin{array}{l}\text { Partially } \\
\text { preserved }\end{array}$ & $\begin{array}{l}\text { Partially } \\
\text { preserved }\end{array}$ & $\begin{array}{l}\text { Lightweight/ } \\
\text { transparent } \\
\text { materials; } \\
\text { movable walls; } \\
\text { glass surfaces }\end{array}$ & $\begin{array}{l}\text { Use of local } \\
\text { constru. mater.; } \\
\text { urban green } \\
\text { spaces; outdoor } \\
\text { water body }\end{array}$ & $\begin{array}{l}\text { Performing } \\
\text { arts; } \\
\text { Workshops; }\end{array}$ & $\begin{array}{l}\text { High } \\
\text { convenience }\end{array}$ \\
\hline $\begin{array}{l}\text { Group } \\
05\end{array}$ & $\begin{array}{l}\text { Showroom; } \\
\text { souvenir shop; } \\
\text { library; café; } \\
\text { administration }\end{array}$ & $\begin{array}{l}\text { Historical; } \\
\text { urban; } \\
\text { architectural; } \\
\text { memorial; }\end{array}$ & $\begin{array}{l}\text { Partially } \\
\text { preserved }\end{array}$ & $\begin{array}{l}\text { Partially } \\
\text { preserved }\end{array}$ & $\begin{array}{l}\text { Largely } \\
\text { preserved }\end{array}$ & $\begin{array}{l}\text { Lightweight/ } \\
\text { transparent } \\
\text { materials; } \\
\text { glass } \\
\text { openings; } \\
\text { glass surfaces }\end{array}$ & $\begin{array}{l}\text { Use of local } \\
\text { construction } \\
\text { materials; green } \\
\text { roof and solar } \\
\text { panels }\end{array}$ & $\begin{array}{l}\text { Workshops; } \\
\text { Social } \\
\text { practices; }\end{array}$ & $\begin{array}{l}\text { Great } \\
\text { convenience }\end{array}$ \\
\hline
\end{tabular}

Figure 17. Comparative analysis of student proposals for protection, revitalization and presentation of the Mint “A.D." complex according to sustainability criteria. 
As we have shown in the section dedicated to the results of the work, obsolete and abandoned industrial sites form important zones for potential progressive economic development of the city through the encouragement of tourism, culture, recreation, catering and other creative functions. Therefore, urban regeneration is an important mechanism that aims to improve a particular area in the city especially guided by sustainable development practice and goals. Industrial heritage is a part of the architectural and urban memory of the city, as it testifies to the changes that have taken place throughout history through its material and intangible aspects.

By destroying these ruined parts of the city, a part of the history of an urban space is lost, as well as the continuity of culture and its development in a certain area. Therefore, revitalization and conservation are vital steps in preserving industrial heritage and its cultural, architectural-urban, aesthetic and historical values in order to create the integrity of the development of the new in the preservation of the old.

As proved by the presented student research projects, the benefits of revitalization are numerous: preservation and renewal of industrial heritage, environmental, cultural, economic and social revitalization of certain parts of the city and their reaffirmation, increasing the attractiveness of these areas, increasing development in terms of attracting other functions located nearby. By implementing adequate reuse and renovation, revitalized buildings and sites of industrial cultural heritage can become the main driver of change that can fully revive and reaffirm the urban, natural and social environment.

What is common to all countries in transition is that urban development is proceeding at a much faster pace than in developed countries because there is a desire to rapidly modernize society and accelerate the process of urbanization. In that sense, various participants and interest groups are involved in the processes of protection and revitalization of urban units. All this often results in poor proposals, ideas and projects that are very often destructively directed towards cultural heritage, or very often excessive and inappropriate content is introduced into the environment of historical monuments and sites. All this takes place under ambiguous political goals that are hidden behind justifications such as more progressive and harmonized development of the society, the city, the industry and the economy.

Laws and regulations in the field of cultural heritage preservation in Serbia did not follow the changes in legislation in other developed European countries and were not harmonized with other national laws, as a result of which, cultural monuments and protection services in Serbia were placed in an unsatisfactory position. In that sense, it is necessary to change the attitude towards cultural heritage, and prevent negative aspects that affect the development of the city, such as: (a) inadequate consideration of the relationship between city development projects and the principle of cultural heritage preservation, which often leads to bad plans and harmful impact on the natural and cultural heritage, as well as on the way of life of the local population; (b) city development projects based on inadequate understanding of complex and often conflicting important characteristics of a particular historical area can lead to loss of its authenticity and identity; and (c) lack of adequate and appropriate presentation of the importance of preserving cultural heritage to all members of society, government, citizens, local communities and visitors, can lead to misunderstanding and poor attitudes towards the cultural and historical heritage of a particular area in a broader sense.

Based on the above, it can be concluded that these problems are in line with the views of modern protection methodology and that laws and strategies defining the field of urbanism and architecture offer a framework for an integrative and self-sustainable approach to cultural heritage protection, which is also required in modern approaches to the protection, revitalization and presentation of urban units, historical spaces and industrial complexes. It is necessary to devise long-term plans for the Belgrade riverfront, along the Sava and Danube Rivers, which will increasingly include various governmental and civil initiatives that will make the space attractive for investment, yet preserving the cultural-historical character, urban morphology and historical construction fund.

During future urban planning and architectural design, radical and destructive changes must not be allowed, such as the demolition of old residential buildings, industrial buildings and complexes, 
and the construction of new buildings of dominant heights that permanently destroy spatial views. On the contrary, realistic and coordinated changes should be planned, that will take into account the integrity of tangible and intangible urban and architectural heritage. In that way, dynamic, colorful and creative historical spaces with their surroundings would be realized, which would represent a combination of the old and the new in accordance with the modern needs of society. By establishing monitoring, the plan for the protection, revitalization and presentation of the Belgrade banks of the Sava and Danube Rivers will be consistently implemented. Monitoring should consist of two segments: (a) monitoring the situation as a whole and (b) monitoring the implementation of the plan. Adequately conducted monitoring is of great importance for urban planners and city authorities.

\section{Conclusions}

In accordance with the recommendations of the Charter on the Preservation of Industrial Heritage [2] and education in the field of protection of architectural heritage, it can be concluded that teaching at the University of Belgrade-Faculty of Architecture fully follows the general direction and scope that exists in other European countries. Through work on the course History and Theory 1-Visual Culture in Architectural Theory and Practice, during a one-semester course in the school year 2019/2020, students were able to get acquainted with modern principles of protection, revitalization and presentation of industrial heritage in the world and to apply the acquired knowledge on a specific example of industrial heritage in Belgrade. Through work on specific topics related to research, valorization, protection and revitalization of architectural heritage, students were able to develop and enrich their knowledge in solving many contemporary problems in the protection and revitalization of historic sites and environments. Accordingly, the students' conceptual projects involving the Mint "A.D." were filled with numerous new contents, with the aim of improving the historical, cultural and technical values that this complex possesses.

From the enclosed student conceptual projects of revitalization and presentation of the Mint "A.D.", a contribution was made to the research of the development of industrial architecture of the city, but also to designing the possibilities of its reactivation through new cultural-artistic, educational and catering contents that would preserve this important example of technical culture. The machines and elements of technical culture, which were found on the spot, are planned to be part of the future revitalization and presentation in student projects, which is in line with the recommendations on preserving industrial heritage. In that way, the dynamic concept of constant enrichment of the authenticity of the historical place was followed, through the changes and diversions brought by the historical time, with the necessary compliance with the guidelines from international charters and recommendations.

In Serbia, the concept of sustainability is still not adequately represented neither in architectural design planning, nor in business. This is why such research papers primarily aim to arouse interest, encouraging young initiatives of future generations to raise and inform the public about the importance of issues that are of existential significance for our future. The presented educational projects provide practical and theoretical models of a new methodology of work that includes all the differences and contradictions of our time and tries to include a variety of elements and factors, as well as to provide maximum results through maximum care for the environment in pursuit of universal goals of sustainable development.

Sustainability is not only in preserving the architecture of old industrial heritage and reducing electricity consumption, but in such a way of architectural construction that will not disturb the local range of resilience, as well as in the fact that architectural and urban interventions should not endanger the health of ecosystems. Therefore, the preservation of architectural heritage and new building construction should improve the health of the urban, natural and social environment, with investment in sustainable architecture and urban planning being the best capital of the future. 
Author Contributions: Conceptualization, M.N., B.D. and I.K.Ć.; Methodology, M.N., B.D. and I.K.Ć.; Validation, M.N., B.D. and I.K.Ć.; Formal analysis, M.N., B.D. and I.K.Ć.; Investigation, M.N., B.D. and I.K.Ć.; Resources, M.N., B.D. and I.K.Ć.; Data curation, B.D.; Writing—original draft preparation, M.N., B.D. and I.K.Ć.; Writing一review and editing, M.N., B.D. and I.K.Ć.; Visualization, B.D.; Supervision, M.N.; Project Administration, I.K.Ć.; Funding acquisition, M.N., B.D. and I.K.Ć. All authors have read and agreed to the published version of the manuscript.

Funding: This research received no external funding.

Acknowledgments: We thank the anonymous reviewers who contributed suggestions to improve the quality of the paper, the Academic Editors, all the MDPI staff for their valuable work, Faculty of Architecture University of Belgrade, students and colleagues for their contribution.

Conflicts of Interest: The authors declare no conflict of interest.

\section{References}

1. Tasić, N.; Zotović, L.j.; Kalić, J.; Tričković, R.; Milosavljević, P.; Milić, D.; Maksimović, B.; Kojić, B.; Milićević, J.; Gligorijević, B.; et al. Istorija Beograda; Srpska akademija nauka i umetnosti: Belgrade, Serbia, 1995.

2. TICCIH (The International Committee for the Conservation of the Industrial Heritage). The Nizhny Tagil Charter for the Industrial Heritage; TICCIH: Ceredigion, UK, 2003.

3. Palmer, M.; Neaverson, P. Industrial Archaeology. In Principles and Practice; Routledge: London, UK; New York, NY, USA, 2001; pp. 1-2.

4. Council of Europe Industrial Heritage in Europe; Council of Europe, Parliamentary Assembly: Brussels, Belgium. 2013. Available online: http://assembly.coe.int/nw/xml/XRef/Xref-XML2HTML-en.asp?fileid= 19512\&lang=EN (accessed on 14 January 2020).

5. ICOMOS (International Council of Monuments and Sites). Venice Charter for the Conservation and Restoration of Monuments and Sites; ICOMOS: Venice, Italy, 1964.

6. UNESCO (United Nations Educational, Scientific and Cultural Organization). Convention Concerning the Protection of the World Cultural and Natural Heritage; UNESCO: Paris, France, 1972.

7. Council of Europe. Convention for the Protection of the Architectural Heritage of Europe; Council of Europe: Granada, Spain, 1985.

8. UNESCO (United Nations Educational, Scientific and Cultural Organization). Convention for the Safeguarding of the Intangible Cultural Heritage; UNESCO: Paris, France, 2003.

9. Petranović, B. Istorija Jugoslavije 1918-1988, Knjige 1,2,3; Nolit: Belgrade, Yugoslavia, 1988.

10. Ignjatović, A. Jugoslovenstvo u arhitekturi 1904-1941; Građevinska knjiga: Belgrade, Serbia, 2007.

11. Belgrade, W. Available online: https://www.belgradewaterfront.com/en/ (accessed on 22 January 2020).

12. Academy of Architecture of Serbia. Available online: https://aas.org.rs/tag/beograd-na-vodi/ (accessed on 22 January 2020).

13. National Sustainable Development Strategy [Nacionalna strategija održivog razvoja]. Offcial Gazette of the Republic of Serbia [Službeni glasnik Republike Srbije] br. 57/2008; Službeni glasnik: Belgrade, Serbia, 3 June 2008.

14. Museum of Science and Technology. Protocol for the Integral Protection of Industrial Heritage; MST: Belgrade, Serbia, 2007.

15. Lalović, K.; Živković, J.; Radosavlejvić, U.; Đukanović, Z. An Integral Approach to the Modeling of Information Support for Local Sustainable Development-Experiences of a Serbian Enabling Leadership Experiment. Sustainability 2019, 11, 2675. [CrossRef]

16. Nikezić, A.; Marković, D. Place-Based Education in the Architectural Design Studio: Agrarian Landscape as a Resource for Sustainable Urban Lifestyle. Sustainability 2015, 7, 9711-9733. [CrossRef]

17. Radosavljević, U.; Kuletin Ćulafić, I. Use of Cultural Heritage for Place Branding in Educational Projects: The Case of Smederevo and Golubac Fortresses on the Danube. Sustainability 2019, 11, 5234. [CrossRef]

18. Bottero, M.; D'Alpaos, C.; Oppio, A. Ranking of Adaptive Reuse Strategies for Abandoned Industrial Heritage in Vulnerable Contexts: A Multiple Criteria Decision Aiding Approach. Sustainability 2019, 11, 785. [CrossRef]

19. Coscia, C.; Lazzari, G.; Rubino, I. Values, Memory, and the Role of Exploratory Methods for Policy-Design Processes and the Sustainable Redevelopment of Waterfront Contexts: The Case of Officine Piaggio (Italy). Sustainability 2018, 10, 2989. [CrossRef] 
20. ICOMOS (International Council of Monuments and Sites). The Nara Document on Authenticity; ICOMOS: Nara, Japan, 1994.

21. ICOMOS (International Council of Monuments and Sites). The Nara+20: On Heritage Practices, Cultural Values and the Concept of Authenticity; ICOMOS: Nara, Japan, 2014.

22. ICOMOS (International Council of Monuments and Sites). International Cultural Tourism Charter: Managing Tourism at Places of Heritage Significance; ICOMOS: Mexico City, Mexico, 1999.

23. World Summit on Sustainable Tourism. The 2015 World Charter for Sustainable Tourism +20; World Summit on Sistainable Tourism: Victoria-Gasteiz, Spain, 2015.

24. TICCIH (The International Committee for the Conservation of the Industrial Heritage). Taipei Declaration for Asian Industrial Heritage. In Proceedings of the TICCIH Congress 15th Congress in Taipei, Taipei, Taiwan, 5-8 November 2012.

25. Council of Europe. Council of Europe Framework Convention on the Value of Cultural Heritage for Society; Council of Europe: Faro, Portugal, 2005.

26. Council of Europe. European Landscape Convention; Council of Europe: Florence, Italy, 2000.

27. Council of Europe. Congress of Local and Regional Authorities of Europe. Manifesto for a New Urbanity: European Urban Charter II; Council of Europe: Congress of Local and Regional Authorities of Europe: Strasbourg, France, 2008.

28. TICCIH (The International Committee for the Conservation of the Industrial Heritage). Available online: https://ticcih.org (accessed on 7 February 2020).

29. TICCIH (The International Committee for the Conservation of the Industrial Heritage). Available online: https://ticcih.org/ticcih-in-chile-congress-xvii (accessed on 8 February 2020).

30. TICCIH (The International Committee for the Conservation of the Industrial Heritage). Memorandum of Understanding between ICOMOS and TICCIH Regarding a Framework for Collaboration on the Conservation of Industrial heritage; TICCIH: Ceredigion, UK, 2014.

31. ERIH (European Route of Industrial Heritage). European Route of Industrial Heritage: Executive Summary: Our Common European Heritage; ERICH Secretariat Deutsche Gesellschaft für Industriekultur: Duisburg, Germany, 2001. Available online: https://www.erih.net/fileadmin/Mediendatenbank/Downloads/Masterplan__Infos/ ERIH_I_summary.PDF (accessed on 12 January 2020).

32. ERIH (European Route of Industrial Heritage). The Declaration of Duisburg; ERICH Secretariat Deutsche Gesellschaft für Industriekultur: Duisburg, Germany, 2001. Available online: https://www.erih.de (accessed on 12 January 2020).

33. ICOMOS (International Council of Monuments and Sites). The ICOMOS Charter on Cultural Routes. In Proceedings of the 16th General Assembly of ICOMOS, Québec, QC, Canada, 29 September-5 October 2008.

34. UNESCO (United Nations Educational, Scientific and Cultural Organization). Recommendation on the Historic Urban Landscape; UNESCO World Heritage Centre: Paris, France, 2011.

35. UNESCO (United Nations Educational, Scientific and Cultural Organization). Recommendation Concerning the Safeguarding and Contemporary Role of Historic Areas; UNESCO: Paris, France, 1976.

36. ICOMOS (International Council of Monuments and Sites). Xi'an Declaration on the Conservation of the Setting of Heritage Structures, Sites and Areas; ICOMOS: Paris, France, 2005.

37. UNESCO (United Nations Educational, Scientific and Cultural Organization). Vienna Memorandum on 'World Heritage and Contemporary Architecture-Managing the Historic Urban Landscape'; UNESCO World Heritage Centre: Paris, France, 2005.

38. Congress of Local and Regional Authorities of Europe. Manifesto for a New Urbanity: European Urban Charter II.; Council of Europe: Strasbourg, France, 2008.

39. ICOMOS (International Council of Monuments and Sites). The Québec Declaration on the Preservation of the Spirit of the Place; ICOMOS: Paris, France, 2008.

40. Regionalverband Ruhr. Available online: https://www.route-industriekultur.ruhr (accessed on 15 January 2020).

41. United Nations. Transforming Our World: The 2030 Agenda for Sustainable Development; United Nations: New York, NY, USA, 2015.

42. United Nations. Report of the United Nations Conference on Environment and Development; United Nations: Rio de Janeiro, Brazil, 1992.

43. United Nations. Provisional Agenda; United Nations: Copenhagen, Denmark, 1995. 
44. ICPD. Programme of Action of the International Conference on Population and Development; ICPD: Cairo, Egypt, 1994; extended 2010.

45. United Nations. Resolution adopted by General Assembly, 66/288. The future we want. Final document of the Rio+20 Conference. In Proceedings of the Rio+20 United Nations Conference Sustainable Development, Rio de Janeiro, Brazil, 20-22 June 2012.

46. United Nations. United Nations Millennium Declaration; United Nations: New York, NY, USA, 2000.

47. United Nations. Adoption of the Paris Agreement; United Nations: Paris, France, 2015.

48. United Nations. Kyoto Protocol to the United Nations Framework Convention on Climate Change; United Nations: Kyoto, Japan, 1997.

49. Law on Ratification of the Kyoto Protocol to the United Nations Framework Convention on climate change [Zakon o potvrđivanju Kjoto protokola uz okvirnu konvenciju Ujedinjenih Nacija o promeni klime]. Official Gazette of the Republic of Serbia [Službeni glasnik Republike Srbije] br. 88/07; Službeni glasnik: Belgrade, Serbia, 2007.

50. United Nations. Doha Amendment the Kyoto Protocol; United Nations: Doha, Qatar, 2012.

51. Muminović, E.; Radosavljević, U.; Beganović, D. Strategic Planning and Management Model for the Regeneration of Historic Urban Landscapes: The Case of Historic Center of Novi Pazar in Serbia. Sustainability 2020, 12, 1323. [CrossRef]

52. Radosavljević, U.; Đorđević, A.; Živković, J.; Lalović, K.; Đukanović, Z. Educational Projects for Linking Place Branding and Urban Planning in Serbia, European Planning Studies. 2019. Available online: https://www.tandfonline.com/doi/full/10.1080/09654313.2019.1701296 (accessed on 14 January 2020).

53. Landry, C. The Creative City: A Toolkit for Urban Innovators; Comedia Earthscan Publishing for a Sustainable Future: London, UK; Sterling, VA, USA, 2008; pp. 166-167.

54. Radosavljević, U.; Đorđević, A.; Živković, J. Business Improvement Districts as a Management Instrument for City Center's Regeneration in Serbia. Facta Univ. Ser. Archit. Civ. Eng. 2015, 13, 11-22. [CrossRef]

55. Lalović, K.; Radosavljević, U.; Đukanović, Z. Reframing Public Interest in the Implementation of Large Urban Projects in Serbia: The Case of Belgrade Waterfront Project. Facta Univ. Ser. Archit. Civ. Eng. 2015, 13, 35-46. [CrossRef]

56. Nikolić, M.; Pašić, D.; Milenković, A. Ispitivanje mogućnosti zaštite i revitalizacije livnice Panteliću Zemunu. Nasleđe 2018, XIX, 149-161.

57. Roter Blagojević, M.; Nikolić, M. Predlog revitalizacije umetničke livnice Skulptura. Nasleđe 2012, XIII, 221-234.

58. Vujović, B. Beograd u prošlosti i sadašnjosti; Izdavačka agencija Draganić: Belgrade, Serbia, 1994.

59. Janićijević, J.; Vujović, B.; Jovanović, M.; Kusovac, N.; Nemanjić, M.; Pantelić, N.; Srejović, D.; Stanić, D. Kulturna riznica Srbije; Izdavačka zadruga IDEA: Belgrade, Serbia, 1996; pp. 233-269.

60. Roter Blagojević, M. The Modernization and Urban Transformation of the Belgrade in the 19th and Early 20th Century. In Planing Capital Cities: Belgrade, Bucurest, Sofia; Doytchinov, G., Đukić, A., Catalina, I., Eds.; Verlag der Technischen Universität Graz: Graz, Austria, 2015; pp. 20-42.

61. Kulenović, R. Industrijsko Nasleđe Beograda; Muzej nauke i tehnike: Belgrade, Serbia, 2010.

62. Katalog Nepokretnih Kulturnih Dobara Na Području Grada Beograda (The Cultural Properties in Belgrade). Available online: http://beogradskonasledje.rs/kd/zavod/savski_venac/zeleznicka_stanica.html (accessed on 6 April 2020).

63. Vukotić-Lazar, M.; Roter Blagojević, M. The 1923 Belgrade Master Plan-historic town modernization. Planning Perspectives. 2017, pp. 1-8. Available online: https://doi.org/10.1080/02665433.2017.1408485 (accessed on 26 April 2020).

64. Petrović, D. Istorija Industrije Beograda. Razvoj I Razmestaj Industrije Beograda U XIX I XX Veku; Srpsko geografsko društvo: Belgrade, Serbia, 2006.

65. Mihajlov, S. Nastanak i razvoj industrijske zone na desnoj obali Dunava u Beogradu od kraja 19. do sredine 20. veka. Nasleđe 2011, XII, 91-116.

66. Djukić, A.; Vaništa Lazarević, E.; Vukmirović, M. Planning framework, projects, urban competitions and visions for development of Sava Amphitheatre. Izgradnja 2014, 3-4, 103-121.

67. Law on Cultural Property [Законо културним добрима]. Official Gazette of the City of Belgrade [Službeni list grada Beograda]. No. 71/94,52/2011, 99/11. Available online: http://www.kultura.gov.rs/docs/dokumenti/ propisi-iz-oblasti-kulture/zakon-o-kulturnim-dobrima.pdf (accessed on 26 April 2020). 
68. Obad Šćitaroci, M.; Bojanić Obad Šćitaroci, B. Heritage Urbanism. Sustainability 2019, 11, 2669. [CrossRef]

69. Milinković, M.; Ćorović, D.; Vuksanović-Macura, Z. Historical Enquiry as a Critical Method in Urban Riverscape Revisions: The Case of Belgrade's Confluence. Sustainability 2019, 11, 1177. [CrossRef]

70. Katalog Nepokretnih Kulturnih Dobara Na Području Grada Beograda (The Cultural Properties in Belgrade). Available online: http://beogradskonasledje.rs/kd/zavod/stari_grad/beogradska_tvrdjava.html (accessed on 6 April 2020).

71. Katalog Nepokretnih Kulturnih Dobara Na Području Grada Beograda (The Cultural Properties in Belgrade). Available online: http://beogradskonasledje.rs/kd/zavod/stari_grad/kosancicev_venac.html (accessed on 6 April 2020).

72. Rosenfield, K. Beton Hala Waterfront Center / Sou Fujimoto Architects, ArchDaily. 2012. Available online: https://www.archdaily.com/286381/beton-hala-waterfront-center-sou-fujimoto-architects/ISSN07198884 (accessed on 3 May 2020).

73. Vaništa Lazarević, E. Urban Regeneration Tools (City Branding) in Belgrade after the Democratic Change in 2000-Social Frame. In Planing Capital Cities: Belgrade, Bucurest, Sofia; Doytchinov, G., Đukić, A., Catalina, I., Eds.; Verlag der Technischen Universität Graz: Graz, Austria, 2015; pp. 174-187.

74. Roter Blagojević, M.; Nikolić, M. Dilemmas and Problems in Active Reuse of Belgrade Industrial Architecture-The Case Study of the Sava River Area. In e-Monographic Publication of ICOMOS Slovenia: Protection and Reuse of Industrial Heritage: Dilemmas, Problems, Examples; Ifko, S., Stokin, M., Eds.; ICOMOS Slovenia: Ljubljana, Slovenia, 2017; pp. 25-35.

75. Katalog Nepokretnih Kulturnih Dobara Na Području Grada Beograda (The Cultural Properties in Belgrade). Available online: http://beogradskonasledje.rs/kd/zavod/savski_venac/zgrada_drzavne_stamparije.html (accessed on 19 April 2020).

76. Katalog Nepokretnih Kulturnih Dobara Na Području Grada Beograda (The Cultural Properties in Belgrade). Available online: http://beogradskonasledje.rs/kd/zavod/savski_venac/fabrika_hartije_milana_vape.html (accessed on 19 April 2020).

77. Katalog Nepokretnih Kulturnih Dobara Na Području Grada Beograda (The Cultural Properties in Belgrade). Available online: http://beogradskonasledje.rs/kd/zavod/savski_venac/hala_1_beogradskog_sajma.html (accessed on 19 April 2020).

78. Katalog Nepokretnih Kulturnih Dobara Na Području Grada Beograda (The Cultural Properties in Belgrade). Available online: http://beogradskonasledje.rs/kd/zavod/cukarica/fabrika_secera.html (accessed on 19 April 2020).

79. Djukić, A.; Špirić, A.; Vujičić, T. Urban Design Competition and Megaprojects in a Context of Identity of Cultural Heritage: Case Study Belgrade's Riverfronts. In e-Monographic Publication of ICOMOS Slovenia: Protection and Reuse of Industrial Heritage: Dilemmas, Problems, Examples; Ifko, S., Stokin, M., Eds.; ICOMOS Slovenia: Ljubljana, Slovenia, 2017; pp. 59-71.

80. Katalog Nepokretnih Kulturnih Dobara Na Području Grada Beograda (The Cultural Properties in Belgrade). Available online: http://beogradskonasledje.rs/kd/zavod/stari_grad/termoelektrana_snaga_i_svetlost.html (accessed on 19 April 2020).

81. Drobnjak, B.; Nikolić, M. Bauhaus i njegova refleksija na formiranje umetničkih praksi na eks-jugoslovenskim kulturnim prostorima (Bauhaus and its Reflection on Forming of the Artistic Practices in the Ex-Yugoslav Cultural Region). Arhit. I Urban. 2019, 49, 7-17.

82. "BBC Dream Builders"-Interview with Norman Foster. Interview conducted by Razia Iqbal (BBC World Service, 16.06.2013, London, United Kingdom). Available online: https://www.fosterandpartners.com/media/ 1028028/NF-BBC-Dream_Builders_transcript.pdf (accessed on 15 January 2020).

83. Foster and Partners. 2020. Available online: https://www.fosterandpartners.com/expertise/sustainability/ (accessed on 4 January 2020).

84. General Urban Plan for Belgrade [Generalni urbanistički plan Beograda]. Official Gazette of the City of Belgrade [Službeni list grada Beograda]; Službeni glasnik: Belgrade, Serbia, 2016.

85. UNESCO (United Nations Educational, Scientific and Cultural Organization). The UNESCO Recommendation on the Historic Urban Landscape; UNESCO World Heritage Centre: Paris, France, 2019. Available online: https://whc.unesco.org/en/hul/ (accessed on 22 January 2020).

86. Latham, D. Creative Re-Use of Buildings; Donhead Publishing: Shaftesbury, UK, 2000; Volume 2. 
87. Yung, E.H.K.; Chan, E.H.W. Implementation challenges to the adaptive reuse of heritage buildings: Towards the goals of sustainable, low carbon cities. Habitat Int. 2012, 36, 352-361. [CrossRef]

88. Nocca, F. The Role of Cultural Heritage in Sustainable Development: Multidimensional Indicators as Decision-Making Tool. Sustainability 2017, 9, 1882. [CrossRef]

89. World Health Organization. The WHO special initiative for mental health (2019-2023): Universal health coverage for mental health; World Health Organization, 2019. Available online: https://apps.who.int/iris/ handle/10665/310981 (accessed on 26 January 2020).

90. United Nations. Our Common Future: Report of the World Commission on Environment and Development-Brundtland Report; United Nations: New York, NY, USA, 1987. Available online: https://sustainabledevelopment.un.org/content/documents/5987our-common-future.pdf (accessed on 19 January 2020).

91. Evans, J.; Jones, P. Rethinking Sustainable Urban Regeneration: Ambiguity, Creativity, and the Shared Territory. Environ. Plan. A 2008, 40, 1416-1434. [CrossRef]

92. De Berardinis, P.; Rotilio, M.; Capannolo, L. Energy and Sustainable Strategies in the Renovation of Existing Buildings: An Italian Case Study. Sustainability 2017, 9, 1472. [CrossRef]

93. Günçe, K.; Misırlısoy, D. Assessment of Adaptive Reuse Practices through User Experiences: Traditional Houses in the Walled City of Nicosia. Sustainability 2019, 11, 540. [CrossRef]

94. Radosavljević, U.; Đorđević, A.; Lalović, K.; Živković, J.; Đukanović, Z. Nodes and Networks: The Generative Role of Cultural Heritage for Urban Revival in Kikinda. Sustainability 2019, 11, 2509. [CrossRef]

95. Yoon, J.; Lee, J. Adaptive Reuse of Apartments as Heritage Assets in the Seoul Station Urban Regeneration Area. Sustainability 2019, 11, 3124. [CrossRef]

96. De Medici, S.; De Toro, P.; Nocca, F. Cultural Heritage and Sustainable Development: Impact Assessment of Two Adaptive Reuse Projects in Siracusa, Sicily. Sustainability 2020, 12, 311. [CrossRef]

97. Howkins, J. The Creative Economy How People Make Money from Ideas; The Penguin Press: London, UK, 2001; pp. 86-87.

98. Harries, K. The Ethical Function of Architecture; MIT Press: Massachusetts, NE, USA, 2000; p. 270.

99. Delancey, C. Architecture can Save the World: Building and Environmental Etics. In the Philosophical Forum; Blackwell Publishing Ltd.: Oxford, UK; Malden, MA, USA, 2004; Volume 35, pp. 147-159.

100. Gradska Opština Savski Venac (Municipality Savski Venac). 2016. Available online: https://www.savskivenac. rs/cir/o-opstini/ (accessed on 18 April 2020).

101. Bogunović, S. Arhitektonska Enciklopedija Beograda XIX I XX Veka (I); Beogradska knjiga: Belgrade, Serbia, 2005; pp. 355-356.

102. Pavlović, M. Nikola Nestorović; Orion art: Belgrade, Serbia, 2017; p. 46.

103. Pacific Gas and Electric Company. Inclusion of Solar Reflectance and Thermal Emittance Prescriptive Requirements for Residential Roofs in Title 24; Pacific Gas and Electric Company: Sacramento, CA, USA, 2006; p. 3.

104. Solecki, W.D.; Rosenzweig, C.; Cox, J.; Parshall, L.; Rosenthal, J.; Hodges, S. Potential Impact of Green Roofs on the Urban Heat Island Effect. In Green Roofs in the New York Metropolitan Region; Rosenzweig, C., Gaffin, S., Parshall, L., Eds.; Columbia University Center for Climate Systems Research and NASA Goddard Institute for Space Studies: New York, NY, USA, 2006; p. 21.

105. Simić, I.; Stupar, A.; Djokić, V. Building the Green Infrastructure of Belgrade: The Importance of Community Greening. Sustainability 2017, 9, 1183. [CrossRef]

(C) 2020 by the authors. Licensee MDPI, Basel, Switzerland. This article is an open access article distributed under the terms and conditions of the Creative Commons Attribution (CC BY) license (http://creativecommons.org/licenses/by/4.0/). 